\title{
Üniversite Öğrencilerinin Gözünden Evlilik
}

\section{Marriage Through the Eyes of University Students}

\author{
Gökay KELDAL (iD) 1
}

Öz

Bu çalışmanın amacı üniversite öğrencilerinin evliliğe ilişkin görüşlerinin incelenmesidir. Araştırmanın çalışma grubunu 1280 (1003 kadın, 277 erkek) bekâr üniversite öğrencisi oluşturmuştur. Verilerin analizinde yüzde, frekans ve ki-kare analiz teknikleri kullanılmıştır. Elde edilen bulgulara göre üniversite öğrencilerinin büyük bir çoğunluğunun yaşam seyrinde evliliğin yer aldığı, ideal evlilik yaşlarının 26 yaş civarında olduğu, gençlerin büyük bir bölümünün yaşam planlarında önceliğinin kariyer olduğu ve çok az bir kısmının kendini evliliğe hazır hissettiği belirlenmiştir. Üniversite öğrencilerinin üçte birine yakınının evliliklerinin ebeveynlerinin evliliğine benzemesini istediği, üçte birine yakınının evlenmeden birlikte yaşama karşı olumlu yaklaştığı, dörtte birinin evlenmeden cinsel ilişki yaşanmasını uygun bulduğu ve yarıdan fazlasının evlilikten kaygılandığı ortaya çıkarılmıştır.

Anahtar Kelimeler: Evlilik, evliliğe ilişkin görüş, evlilik öncesi faktörler, evlenmeden birlikte yaşam, üniversite öğrencileri

\section{Makale Türü: Araştırma}

\begin{abstract}
This study aims to examine university students' marital views. The study group consisted of 1280 (1003 female, 277 male) single university students. Percentage, frequency and chi-square analysis techniques were used to analyze the data. According to the study findings, majority of university students place marriage in their life course, the ideal marital age is around 26 years, the priority of most of the young people in their life plans is career and very few of them feel ready for marriage. In addition, the study revealed that nearly one third of university students want their marriages to be similar to their parents' marriage, nearly one third of them have a positive attitude towards cohabitation before marriage, one fourth find it appropriate to have premarital sex, and more than half of them are anxious about getting married.
\end{abstract}

Keywords: Marriage, marital view, premarital factors, cohabitation, university students

Paper Type: Research

\footnotetext{
${ }^{1}$ Avrasya Üniversitesi, Fen-Edebiyat Fakültesi, gokay.keldal@avrasya.edu.tr.

Atıf için (to cite): Keldal, G. (2021). Üniversite öğrencilerinin gözünden evlilik. Afyon Kocatepe Üniversitesi Sosyal Bilimler Dergisi, 23(2), 375-393.
} 


\section{Giriş}

Türkiye'de gençlerin büyük bir çoğunluğunun evlenmek istedikleri (Bener ve Günay, 2013), evliliği önemli olarak gördükleri (Bağ, 2019; Can, 2015; Köroğlu, 2013) ve birçoğunun evlilikten korkmadığı (Köroğlu, 2013) bilinmektedir. Her ne kadar araştırmacılar Türkiye'de gençlerin evliliğe önem verdikleri sonucuna ulaşsalar da, Türkiye İstatistik Kurumunun (2020) verileri giderek artan boşanma oranlarını, evlenme sayısındaki azalmaları ve bunların yanı sıra ortalama ilk evlenme yaşının giderek yükseldiğini ortaya koymuştur. Ünal ve Avc1 (2019) gerçekleştirdiği çalışmada bireylerden bir kısmının evlenmeye sıcak bakmadığı bulgusunu elde etmiş̧tir. Akbaş ve diğerleri (2019) gençlerin büyük bir çoğunluğunun aile kurumunda bozulmalar meydana geldiğine inandıklarını belirtmiştir. Özteke-Kozan ve diğerleri (2019) üniversite öğrencisi genç kadınların evlenmeme gerekçeleri arasında evliliğe yönelik korkularının önemli bir yer tuttuğunu belirlemiştir. Araştırmacıların ortaya koyduğu bu zıt bulgular gençlerin evliliğe ilişkin görüşlerinin üzerinde durulmasının önemine işaret etmektedir. $\mathrm{Bu}$ araştırmada da odaklanılan konu üniversite öğrencilerinin evliliğe ilişkin görüşleridir.

Türkiye'de son yıllarda araştırmacıların evlilik öncesi faktörlere odaklandıkları belirlenmiştir. Özellikle, evliliğe ilişkin tutumlar (Akbaş ve diğ., 2019; Bayoğlu ve Atli, 2014; Keldal, 2016; Keldal ve Atli, 2020), evlilikten beklentiler (Öz-Soysal ve diğ., 2020; Keldal, 2017), evliliğin anlamı (Koçyiğit-Özyiğit, 2017; Özabacı ve diğ., 2018) ve eş seçimi (Bozgeyikli ve Toprak, 2013; Sancak-Aydın ve Demir, 2017; Usluoğlu ve diğ.,, 2015) araştırmacıların dikkatini çeken konuların başında gelmektedir. Bu konuların yanı sıra, literatürde gençlerin evliliğe ilişkin görüşlerini inceleyen çalışmaların (Bener ve Günay, 2013; Deniz, 2019; İșmen-Gazioğlu, 2006; Köroğlu, 2013; Ondaş, 2007; Özteke-Kozan ve diğ., 2019; Teke, 2017) olduğu görülmüştür.

Evliliğe ilişkin görüşleri inceleyen bu çalışmalardan Bener ve Günay (2013) üniversite öğrencilerinin evlilik planlarına, evlilik ve aile yaşamındaki rollere ilişkin görüşlerine odaklanmıştır. Benzer olarak, İșmen-Gazioğlu (2006) üniversite öğrencilerinin evlilik ve aile yaşamına ilişkin bazı ifadelere (Örneğin, "Evlilikte örf ve adetler eșlerden biri dahi istese sürdürülmelidir", "İnsanlar gerçek yüzlerini evlendikten sonra gösterirler") katılma düzeylerini ve bu ifadelerde cinsiyet açısından manidar farklılıkları araştırmıştır. Ondaş (2007) üniversite birinci ve dördüncü sinıfta öğrenim gören öğrencilerin evliliğe ilişkin görüşlerini değerlendirmiştir. Köroğlu (2013) ise üniversite öğrencilerinin sadece evlilik ve aile yaşamına ilişkin görüşlerinin ele almamış boşanmaya ilişkin düşüncelerini de incelemiştir. Özteke-Kozan ve diğerleri (2019) üniversite öğrencisi kadınlarla gerçekleştirdiği çalışmada evlenme gerekçeleri, eş adayının özellikleri ve evlenmeme gerekçeleri üzerinde durmuştur.

Teke (2017) üniversite öğrencileriyle gerçekleştirdiği çalışmada, eş seçim kriterleri, evlenmek için gerekli görülen faktörler, evliliğin amaçları ve evlilik öncesi eğitime ilişkin gençlerin görüşlerini ele almıştır. Deniz (2019) yaptığı çalışmada üniversite öğrencisi gençlerin eş adayındaki özelliklere ilişkin görüşlerinin yanı sıra, evlilik öncesi ve evlilik dışı cinselliğe ilişkin düşünceleri, sosyal medyayla tanıştıkları biriyle evlenme durumu ve evlilik sitelerine ilişkin görüşlerini de değerlendirmiştir. Türk kültüründe yapılan bu çalışmalar gençlerin evlilik kurumuyla ilgili düşüncelerini ortaya koysa da, hızlı toplumsal değişimler evlilik olgusundaki değişimleri de hızlandırmıştır. Özellikle, batı toplumlarında evliliğin alternatifi olarak evlenmeden birlikte yaşamın gösterilmesi (Cherlin, 2004) ve evlenmeden birlikte yaşamın giderek yaygınlaşması (Kuperberg, 2019; Lichter ve diğ., 2010) bu değişimlerin bir nedeni olarak görülebilir. Bütün bu durumlar gençlerin evlilikle ilgili düşüncelerinde de çabuk değişimlere sebep olabilir.

Evlilik kurumundaki bu gelişmeler araştırmacıların gençlerin evlilikle ilgili inançlarına odaklanmalarını sağlamıştır. Bu bağlamda, gençlerin evliliğe yönelik inançlarının anlaşılması noktasında Carroll ve diğerleri (2007) Evlilik Ufku Kuramı ve Willoughby ve diğerleri (2015b) Evlilik Paradigması Kuramını ileri sürmüşlerdir. Bu kuramların ileri sürülmesiyle birlikte son 
on yılda bilim insanları gençlerin evlilikle ilgili düşüncelerini de ele almışlardır. Carroll ve diğerleri (2009) gençlerin büyük bir çoğunluğunun kendilerini evliliğe hazır hissetmediğini belirlemişlerdir. Willoughby ve Dworkin (2009) gençlerin yaklaşık dörtte birinin şu an evlenmek istedikleri sonucuna ulaşmıştır. Barr ve Simons (2018) gençlerin \% 57'sinin iyi bir evliliğe sahip olmanın son derece önemli olduğunu düşündüklerini rapor etmişlerdir. Elde edilen bu bulgular toplumlar açısından önem arz eden evlilik olgusuna ilişkin gençlerin evlilik birliğini oluşturup oluşturmamaları ve evliliklerini yürütebilmeleri hakkında bir kestirimde bulunmayı sağlayabilir.

Özellikle, Amerika gibi batı toplumlarında gençlerin evliliğe ilişkin inançları ve görüşleri sık sık değerlendirilirken, Türkiye de gençlerin evlilikle ilgili görüşleriyle ilgili sınırlı sayıda çalışma olduğu ifade edilebilir. Daha önceki yapılan çalışmalarda (Akbaş ve diğ., 2019; Bener ve Günay, 2013; Deniz, 2019; Köroğlu, 2013; Ondaş, 2007; Teke, 2017) benzer konulara odaklanıldığı bilinmektedir. Bu durum üniversite öğrencisi gençlerin evlilikle ilgili görüşlerini incelerken birçok noktalarda eksiklikler oluşmasına neden olmaktadır. Türk toplumu açısından önem arz eden evlilik kurumunun korunması için özellikle üniversite öğrenimi gören gençlerin evlilikle ilgili inançlarının kapsamlı bir biçimde incelenmesinin değerli olduğu düşünülmektedir. Ayrıca, bu incelemenin araştırmacılara bu konulara odaklanma hususunda rehberlik edebileceği ifade edilebilir. Bunun yanı sıra, bu çalışmanın sonuçlarının da evlilik öncesi psikolojik danışma alanında uzman olan uygulamacılara yeni bir bakış açısı kazandırabileceği belirtilebilir. Bu bağlamda, Türk kültüründe gençlerin evliliğe verdiği önem, yaşam planlarındaki öncelikleri, evliliğe hazırlık programlarına ilişkin düşünceleri, evlenmeden birlikte yaşam hakkındaki fikirleri ve evlilik öncesi cinselliğe ilişkin görüşlerinin ele alınarak evlilik öncesi psikolojik danışma literatürdeki önemli bir boşluğu doldurması planlanmaktadır. $\mathrm{Bu}$ doğrultuda, bu çalışmanın amacı üniversite öğrencilerinin evliliğe ilişkin görüşlerinin araştırılmasıdır.

\section{Yöntem}

Üniversite öğrencilerin evliliğe ilişkin görüşlerini inceleyen bu çalışma tarama modelinde tasarlanmıştır. Gay ve diğerleri (2011) tarama araştırmasının, hipotezleri test etmek ya da insanların bir konu veya sorun hakkındaki görüşlerine dair soruları cevaplayabilmek için veri toplamak olduğunu belirtmişlerdir. $\mathrm{Bu}$ çalışmada geniş bir örneklemde üniversite öğrencilerinin evliliğe ilişkin görüşlerinin incelenmesi yönüyle tarama araştırmasıdır.

\section{1. Çalışma Grubu}

Bu araştırmanın çalışma grubunu çeşitli üniversitelerde öğrenim gören 1280 (277 erkek, 1003 kadın) bekâr Türk öğrenci oluşturmuştur. Verilerin toplanmasında uygun örnekleme stratejisi kullanılmıştır. Christensen ve diğerleri (2014) uygun örneklemede çalışmaya en uygun ve kolayca ulaşılabilen kişilerin katıldığını belirtmişlerdir. Bu çalışmaya da uygun olan ve kolay ulaşılabilen üniversite öğrencileri dahil edilmiş̧ir. Araştırmada veri dışlama kriteri olarak evli, nişanlı ve sözlü olma durumları kullanılmıştır. Bu kriterler doğrultusunda 34 gözlem (case) veri setinden çıkarılmıştır. Örneklem grubunda yer alan öğrencilerin yaşları 18-26 ( $\bar{x}=20.34$, ss= 1.48) aralığındadır. Çalışma grubunda yer alan gençlerin 397'sinin (\% 31) romantik bir ilişkisi vardır. Gençlerin \% 89'u ebeveynlerinin evli olduğunu, \% 6's1 ebeveynlerinin boşanmış olduğunu ve \% 5'i de anne veya babalarından en az birinin vefat ettiğini bildirmişlerdir. Örneklemde yer alan gençlerin 106'sı (\% 8) yarı zamanlı ya da tam zamanlı bir işs sahibidir.

\subsection{Prosedür}

Veri toplamaya başlamadan önce Niğde Ömer Halisdemir Üniversitesi etik kuruluna başvurularak araştırma için gerekli görülen etik kurul onayı (2020/06-10) alınmıştır. Araştırmanın verileri 2020 yılının kasım ayında pandemi devam etmesi nedeniyle online olarak toplanmıştır. Üniversite öğrencilerine e-mail ve Whatsapp uygulaması yoluyla ulaşılmıştır. Araştırma hakkında gerekli bilgiler ögrencilere araştırmacı tarafından verilmiştir. Araştırmaya 
katılmayı kabul eden kişilerden bilgilendirilmiş onam formu elde edilmiş̧ir. Araştırmanın sonuçları hakkında bilgi almak isteyenlere e-mail yoluyla dönüt verileceği bildirilmiştir. Katılımcılar formda bulunan 27 maddeyi doldurmuşlardır. Formda bulunan maddelere tepki verme süresi yaklaşık 10 dakika sürmüştür.

\subsection{Veri Toplama Araçları}

$\mathrm{Bu}$ çalışmada veriler araştırmacı tarafından oluşturulan "Evliliğe İlişkin Görüşler Anketi” ile gerçekleştirilmiştir. $\mathrm{Bu}$ anket 20 maddeden oluşmaktadır. $\mathrm{Bu}$ anketin oluşturulmasında Evlilik Ufku Kuramı (Carroll ve diğ., 2007) ve Evlilik Paradigması Kuramı (Willoughby ve diğ., 2015b) temel alınmıştır. Ankette, evliliğe verilen önem, evliliğe hazır olma durumu, ideal evlilik yaşı, evlenme biçimi tercihleri, evliliğe ilişkin kaygı, yaşam planındaki öncelik, evliliğe hazırlık programlarına katılma durumu, evlenmeden birlikte yaşam ve evlilik öncesi cinselliğin kabulüne dair maddeler yer almaktadır. Ankette yer alan sekiz madde gençlerin evliliğe verdikleri önem düzeyini belirlemek için geliştirilmiştir. Bu maddelerin tepki formatı "Kesinlikle Katılmıorum-Kesinlikle Katılıyorum” biçiminde Beşli Likert Ölçeği olarak tasarlanmıştır. Evliliğe verilen önemle ilgili maddeler oluşturulurken Evlilik Ufku Kuramı (Carroll ve diğ., 2007) ve Evlilik Paradigması Kuramının (Willoughby ve diğ., 2015b) yanı sıra daha önceki çalışmalardan da (Jensen ve diğ., 2015; Willoughby ve Hall, 2015) yararlanılmıştır. Ankette yer alan maddeler oluşturulurken uzman görüşlerini başvurulmuştur. Bu sayede hem anketin kapsamlı olması hem de ankette yer alan maddelerin anlaşılır olması hedeflenmiştir. Ayrıca, çalışma grubunda yer alan öğrencilerin kişisel bilgilerini betimlemek için "Kişisel Bilgi Formu" oluşturulmuştur. Kişisel Bilgi Formunda ise gençlerin kişisel bilgilerini belirlemek için yedi madde (cinsiyet, yaş, vb.) yer almıştır.

\subsection{Veri Analizi}

Üniversite öğrencilerinin evliliğe ilişkin görüşlerinin belirlenmesi için verilerin analizinde yüzde, frekans ve Ki-kare analizleri kullanılmıştır. Değişkenler arası ilişkileri belirlemek için Ki-kare tekniğine odaklanılmış ve etki büyüklüğünü belirleyebilmek için Cramér's $V$ hesaplanmıştır. Huck (2011) Cramér's $V$ için .10 küçük, .30 orta ve .50 büyük etki büyüklüğü olarak belirlendiğini ifade etmiştir. $2 \times 3$ tablolarda birinci tip hatay kontrol edebilmek için Green ve Salkind'in (2013) önerileri doğrultusunda Holm's Sequential Bonferroni yöntemi kullanılmıştır. Araştırma da hata payı .05 olarak kabul edilmiştir.

\section{Bulgular}

Evliliğe ilişkin ifade ve sorulara verilen yanıtlara Tablo 1 ve Tablo 2 de yer verilmiştir.

Tablo 1. değişkenlere ilişkin ortalama, standart sapma, yüzde ve frekanslar

\begin{tabular}{|c|c|c|c|c|}
\hline Değişken & $\bar{x}$ & ss & $f$ & $\%$ \\
\hline İdeal evlilik yaş1 & 26.29 & 2.40 & & \\
\hline Kadın & 26.11 & 2.27 & & \\
\hline Erkek & 26.94 & 2.75 & & \\
\hline \multicolumn{5}{|l|}{ Evlilik planı yapma } \\
\hline Evet & & & 1069 & 83 \\
\hline Hayır & & & 211 & 17 \\
\hline \multicolumn{5}{|l|}{ Evliliğe hazır olma } \\
\hline Evet & & & 83 & 7 \\
\hline Bazı konularda evet bazı konularda hayır & & & 518 & 40 \\
\hline Hayır & & & 679 & 53 \\
\hline \multicolumn{5}{|l|}{ Evlenme biçimi } \\
\hline Flört ederek & & & 1191 & 93 \\
\hline Görücü usulü & & & 89 & 7 \\
\hline \multicolumn{5}{|l|}{ Yaşam planındaki öncelik } \\
\hline Evlilik & & & 219 & 17 \\
\hline Kariyer & & & 1061 & 83 \\
\hline
\end{tabular}




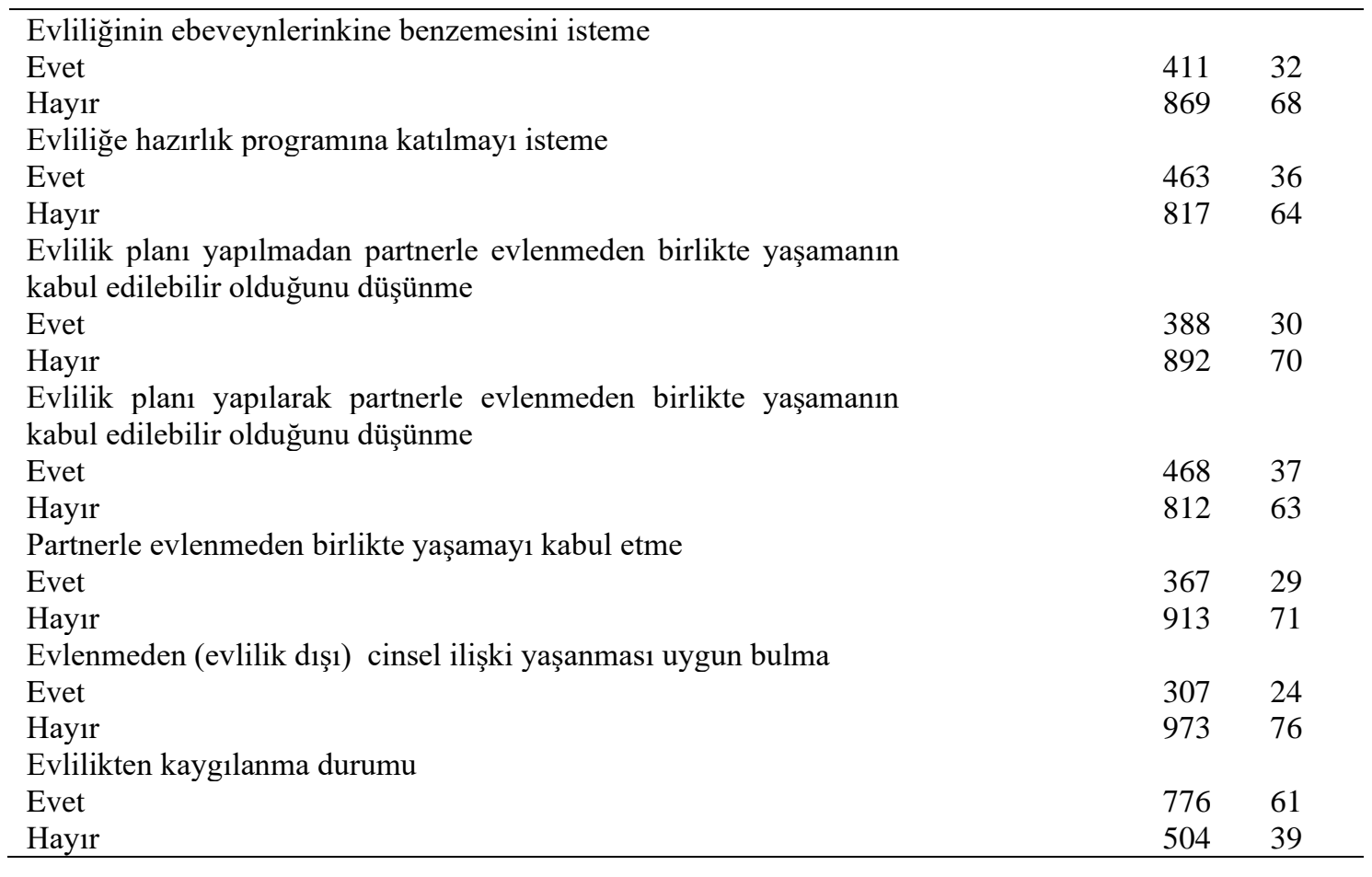

Üniversite öğrencileri ideal evlilik yaşını ortalama 26.29 olarak görmektedirler. Örneklemde yer alan kadınların ideal evlilik yaşına verdikleri cevapların ortalaması 26.11, erkeklerin verdiği yanıtların ortalaması ise 26.94 olarak hesaplanmıştır. Çalışma grubunda yer alanların \%83 yaşam planlarında evlenmenin yer aldığını belirtmişlerdir. Üniversite öğrencilerinin sadece \%7'si evliliğe hazır olduğunu, \%40'1 kısmen hazır olduğunu ve \%53'ü evliliğe hazır olmadıklarını bildirmişlerdir. Gençlerin \%93 evlenme biçimi olarak flört ederek evlenmeyi tercih edeceklerini ifade etmişlerdir. Üniversite öğrencilerinin büyük bir çoğunluğu (\%83) yaşam seyrinde önceliklerinin kariyer olduğunu belirtmişlerdir. Örneklem grubunda yer alan gençlerin \%68'i evliliklerinin ebeveynlerinin evliliğine benzememesini istemektedirler. Üniversite öğrencilerinin \%36's1 evliliğe hazırlanmak için evliliğe hazırlık programına katılabileceklerini beyan etmişlerdir. Gençlerin \%30'u evlilik planı yapılmadan partnerle birlikte yaşamanın kabul edilebilir olduğunu bildirmişlerdir. Üniversite öğrencilerinin \%37'si evlilik planı yapılarak partnerle birlikte yaşamanın kabul edilebilir olduğunu ifade etmişlerdir. Partnerle evlenmeden birlikte yaşayabileceğini ifade eden üniversite öğrencilerinin oranı \% 29 'dur. Evlenmeden (evlilik dışı) cinsel ilişki yaşanmasının uygun olduğunu düşünen üniversite öğrencilerinin oranı \%24'tür. Evlilikten kaygılanan gençlerin oranı ise \%61 olarak bulunmuştur.

Tablo 2. Evliliğin Önemine İlişkin İfadelere Katılma Düzeyi

\begin{tabular}{|c|c|c|c|c|c|}
\hline İfadeler & 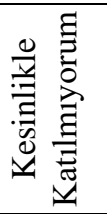 & 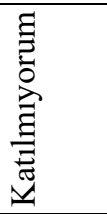 & 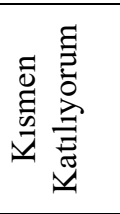 & 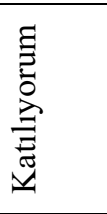 & 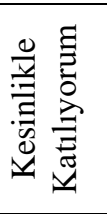 \\
\hline Evlenmeyi önemli bir amaç olarak görüyorum. & $\begin{array}{c}238 \\
(\% 19) \\
\end{array}$ & $\begin{array}{c}206 \\
(\% 16) \\
\end{array}$ & $\begin{array}{c}459 \\
(\% 36) \\
\end{array}$ & $\begin{array}{c}229 \\
(\% 18) \\
\end{array}$ & $\begin{array}{c}148 \\
(\% 11)\end{array}$ \\
\hline Evlenmek, diğer yaşam amaçlarımdan önce gelir. & $\begin{array}{c}517 \\
(\% 41)\end{array}$ & $\begin{array}{c}374 \\
(\% 29)\end{array}$ & $\begin{array}{c}278 \\
(\% 22)\end{array}$ & $\begin{array}{c}81 \\
(\% 6)\end{array}$ & $\begin{array}{c}30 \\
(\% 2)\end{array}$ \\
\hline $\begin{array}{c}\text { Evliliğin bekâr olmaya göre birçok avantajı } \\
\text { olduğuna inanıyorum. }\end{array}$ & $\begin{array}{c}230 \\
(\% 18) \\
\end{array}$ & $\begin{array}{c}300 \\
(\% 23) \\
\end{array}$ & $\begin{array}{c}405 \\
(\% 32) \\
\end{array}$ & $\begin{array}{l}195 \\
(\% 15) \\
\end{array}$ & $\begin{array}{c}150 \\
(\% 12) \\
\end{array}$ \\
\hline Evliliğin gerekli olduğuna inanıyorum. & $\begin{array}{c}160 \\
(\% 13)\end{array}$ & $\begin{array}{c}193 \\
(\% 15) \\
\end{array}$ & $\begin{array}{c}362 \\
(\% 28) \\
\end{array}$ & $\begin{array}{c}292 \\
(\% 23) \\
\end{array}$ & $\begin{array}{c}273 \\
(\% 21) \\
\end{array}$ \\
\hline $\begin{array}{l}\text { Evliliğin geçmişe göre önemini yitirdiğini } \\
\text { düşünüyorum. }\end{array}$ & $\begin{array}{c}106 \\
(\% 8)\end{array}$ & $\begin{array}{c}128 \\
(\% 10)\end{array}$ & $\begin{array}{c}227 \\
(\% 18)\end{array}$ & $\begin{array}{c}308 \\
(\% 24)\end{array}$ & $\begin{array}{c}511 \\
(\% 40)\end{array}$ \\
\hline
\end{tabular}




\begin{tabular}{cccccc}
\hline $\begin{array}{c}\text { Evliliğin özgürlüğümü kısıtlayacağını } \\
\text { düşünüyorum. }\end{array}$ & $\begin{array}{c}261 \\
(\% 20)\end{array}$ & $\begin{array}{c}330 \\
(\% 26)\end{array}$ & $\begin{array}{c}322 \\
(\% 25)\end{array}$ & $\begin{array}{c}212 \\
(\% 17)\end{array}$ & $\begin{array}{c}155 \\
(\% 12)\end{array}$ \\
\hline $\begin{array}{c}\text { Geçmişe kıyasla, evliliği devam ettirebilmek için } \\
\text { daha fazla çabaya gerek olduğuna inanıyorum. }\end{array}$ & $\begin{array}{c}55 \\
(\% 4)\end{array}$ & $\begin{array}{c}54 \\
(\% 4)\end{array}$ & $\begin{array}{c}198 \\
(\% 16)\end{array}$ & $\begin{array}{c}307 \\
(\% 24)\end{array}$ & $\begin{array}{c}666 \\
(\% 52)\end{array}$ \\
\hline $\begin{array}{c}\text { Evlenmemenin yaşamımda önemli bir eksiklik } \\
\text { olacağını düşünüyorum. }\end{array}$ & $\begin{array}{c}318 \\
(\% 25)\end{array}$ & $\begin{array}{c}260 \\
(\% 20)\end{array}$ & $\begin{array}{c}329 \\
(\% 26)\end{array}$ & $\begin{array}{c}202 \\
(\% 16)\end{array}$ & $\begin{array}{c}171 \\
(\% 13)\end{array}$ \\
\hline
\end{tabular}

Üniversite öğrencilerinin \%11'i "Evlenmeyi önemli bir amaç olarak görüyorum" ifadesine kesinlikle katıldıklarını beyan etmiştirler. Gençlerin "Evlenmek, diğer yaşam amaçlarımdan önce gelir" ifadesine yaklaşık \% 41'i kesinlikle katılmadıkları bildirmişlerdir. Örneklem grubunda yer alan bireylerin "Evliliğin bekâr olmaya göre birçok avantaj1 olduğuna inanıyorum" ifadesine sadece \%12'si kesinlikle katıldıklarını belirtmişlerdir. Üniversite öğrencilerinin \% 21'i "Evliliğin gerekli olduğuna inanıyorum" ifadesine kesinlikle katıldıklarını beyan etmişlerdir. Üniversite öğrencilerinin \% 40’1 "Evliliğin geçmişe göre önemini yitirdiğini düşünüyorum" ifadesine kesinlikle katıldıklarını belirtmişlerdir. "Evliliğin özgürlügümü kısıtlayacağını düşünüyorum" ifadesine gençlerin sadece \%12'si kesinlikle katıldıklarını bildirmişlerdir. Üniversite öğrencilerinin \% 52'si “Geçmişe kıyasla, evliliği devam ettirebilmek için daha fazla çabaya gerek olduğuna inanıyorum" ifadesine kesinlikle katıldıklarını belirtmişlerdir. "Evlenmemenin yaşamımda önemli bir eksiklik olacağını düşünüyorum" ifadesine üniversite öğrencilerinin sadece \%13'ü kesinlikle katıldıklarını beyan etmişlerdir.

\subsection{Ki-Kare Analiz Sonuçları}

$\mathrm{Bu}$ çalışmada cinsiyet ve ilişki durumunun; evlilik planı yapma, evliliğe hazır olma, yaşam planındaki öncelik, evliliğinin ebeveynlerinkine benzemesini isteme, evliliğe hazırlık programına katılmayı isteme, evlilik planı yapılmadan partnerle evlenmeden birlikte yaşamanın kabul edilebilir olduğunu düşünme, evlilik planı yapılarak partnerle evlenmeden birlikte yaşamanın kabul edilebilir olduğunu düşünme, partnerle evlenmeden birlikte yaşamayı kabul etme, evlenmeden cinsel ilişki yaşanması uygun bulma ve evlilikten kaygılanma durumlarına ilişkin değişkenlerle ilişkisi ki-kare analiz tekniğiyle incelenmiştir.

Tablo 3. Cinsiyete ilişkin ki-kare analiz sonuçları

\begin{tabular}{|c|c|c|c|c|c|c|c|}
\hline \multirow[t]{2}{*}{ Cinsiyet $^{\mathrm{a}}$} & \multicolumn{2}{|c|}{ Evlilik planı } & \multirow[b]{2}{*}{ Toplam } & \multirow[b]{2}{*}{$\chi^{2}$} & \multirow[b]{2}{*}{$s d$} & \multirow[b]{2}{*}{$p$} & \multirow{2}{*}{$\begin{array}{c}\text { Cramér's } \\
V\end{array}$} \\
\hline & Evet & Hayır & & & & & \\
\hline $\begin{array}{c}\text { Kadın } \\
\text { Cincivetin icinde } 0\end{array}$ & $\begin{array}{l}841 \\
\% 84\end{array}$ & $\begin{array}{l}162 \\
016\end{array}$ & 1003 & & & & \\
\hline Cinsiyetin içinde \% & $\% 84$ & $\% 16$ & & & & & \\
\hline $\begin{array}{c}\text { Erkek } \\
\text { Cinsiyetin içinde \% }\end{array}$ & $\begin{array}{l}228 \\
\% 82\end{array}$ & $\begin{array}{c}49 \\
\% 18\end{array}$ & 277 & .37 & 1 & .54 & - \\
\hline Toplam & 1069 & 211 & 1280 & & & & \\
\hline
\end{tabular}

\begin{tabular}{ccccccccc}
\hline Cinsiyet & \multicolumn{3}{c}{ Evliliğe hazır olma } & \multirow{2}{*}{ Toplam } & \multirow{2}{*}{$\chi^{2}$} & sd & p & Cramér's \\
\cline { 2 - 5 } & Evet & Kısmen & Hayır & & & \\
\hline Kadın & 52 & 411 & 540 & & & & \\
Cinsiyetin içinde $\%$ & $\% 5$ & $\% 41$ & $\% 54$ & 1003 & & & & \\
Hazır olmanın içinde $\%$ & $\% 37$ & $\% 21$ & $\% 20$ & & & & & \\
Erkek & 31 & 107 & 139 & & \multirow{2}{*}{12.92} & 2 & .00 & .10 \\
Cinsiyetin içinde $\%$ & $\% 11$ & $\% 39$ & $\% 50$ & 277 & & & & \\
Hazır olmanın içinde $\%$ & $\% 63$ & $\% 79$ & $\% 80$ & & & & & \\
Toplam & 83 & 518 & 679 & 1280 & & & & \\
\cline { 2 - 5 }
\end{tabular}




\begin{tabular}{|c|c|c|c|c|c|c|c|}
\hline \multirow[t]{2}{*}{ Cinsiyet $^{\mathrm{a}}$} & \multicolumn{2}{|c|}{ Ebeveyn benzeme } & \multirow{2}{*}{ Toplam } & \multirow{2}{*}{$\chi^{2}$} & \multirow{2}{*}{$s d$} & \multirow[b]{2}{*}{$p$} & \multirow{2}{*}{$\begin{array}{c}\text { Cramér's } \\
V\end{array}$} \\
\hline & Evet & Hayır & & & & & \\
\hline Kadın & 305 & 698 & \multirow{2}{*}{1003} & \multirow{5}{*}{6.15} & \multirow{5}{*}{1} & \multirow{5}{*}{.01} & \multirow{5}{*}{.07} \\
\hline Cinsiyetin içinde \% & $\% 30$ & $\% 70$ & & & & & \\
\hline Erkek & 106 & 171 & \multirow{2}{*}{277} & & & & \\
\hline \multirow{2}{*}{$\begin{array}{c}\text { Cinsiyetin içinde } \% \\
\text { Toplam }\end{array}$} & $\% 38$ & $\% 62$ & & & & & \\
\hline & 411 & 869 & 1280 & & & & \\
\hline \multirow[t]{2}{*}{ Cinsiyet $^{\mathrm{a}}$} & \multicolumn{2}{|c|}{ Program } & \multirow{2}{*}{ Toplam } & \multirow{2}{*}{$\chi^{2}$} & \multirow{2}{*}{$s d$} & \multirow{2}{*}{$p$} & \multirow{2}{*}{$\begin{array}{c}\text { Cramér's } \\
V\end{array}$} \\
\hline & Evet & Hayır & & & & & \\
\hline \multirow{5}{*}{$\begin{array}{l}\text { Kadın } \\
\text { Cinsiyetin içinde \% } \\
\text { Erkek } \\
\text { Cinsiyetin içinde \% } \\
\text { Toplam }\end{array}$} & 407 & 596 & \multirow{2}{*}{1003} & \multirow{5}{*}{38.98} & \multirow{5}{*}{1} & \multirow{5}{*}{.00} & \multirow{5}{*}{.18} \\
\hline & $\% 41$ & $\% 59$ & & & & & \\
\hline & 56 & 221 & \multirow{2}{*}{277} & & & & \\
\hline & $\% 20$ & $\% 80$ & & & & & \\
\hline & 463 & 817 & 1280 & & & & \\
\hline \multirow[t]{2}{*}{ Cinsiyet $^{\mathrm{a}}$} & \multicolumn{2}{|c|}{ Plan Yapilmadan } & \multirow{2}{*}{ Toplam } & \multirow{2}{*}{$\chi^{2}$} & \multirow{2}{*}{$s d$} & \multirow[b]{2}{*}{$p$} & \multirow{2}{*}{$\begin{array}{c}\text { Cramér's } \\
V\end{array}$} \\
\hline & Evet & Hayır & & & & & \\
\hline Kadın & 279 & 724 & 1003 & & & & \\
\hline Cinsiyetin içinde \% & $\% 28$ & $\% 72$ & 1003 & & & & \\
\hline Erkek & 109 & 168 & 277 & 13.67 & 1 & .00 & .10 \\
\hline Cinsiyetin içinde \% & $\% 39$ & $\% 61$ & 211 & & & & \\
\hline Toplam & 388 & 892 & 1280 & & & & \\
\hline
\end{tabular}

\begin{tabular}{|c|c|c|c|c|c|c|c|}
\hline \multirow[t]{2}{*}{ Cinsiyet $^{\mathrm{a}}$} & \multicolumn{2}{|c|}{ Plan Yapılarak } & \multirow{2}{*}{ Toplam } & \multirow{2}{*}{$\chi^{2}$} & \multirow{2}{*}{$s d$} & \multirow{2}{*}{$p$} & \multirow{2}{*}{$\begin{array}{c}\text { Cramér's } \\
V\end{array}$} \\
\hline & Evet & Hayır & & & & & \\
\hline Kadın & 342 & 661 & \multirow{2}{*}{1003} & \multirow{5}{*}{12.14} & \multirow{5}{*}{1} & \multirow{5}{*}{.00} & \multirow{5}{*}{.10} \\
\hline Cinsiyetin içinde $\%$ & $\% 34$ & $\% 66$ & & & & & \\
\hline Erkek & 126 & 151 & \multirow{2}{*}{277} & & & & \\
\hline \multirow{2}{*}{$\begin{array}{c}\text { Cinsiyetin içinde } \% \\
\text { Toplam }\end{array}$} & $\% 46$ & $\% 54$ & & & & & \\
\hline & 468 & 812 & 1280 & & & & \\
\hline \multirow[t]{2}{*}{ Cinsiyet $^{\mathrm{a}}$} & \multicolumn{2}{|c|}{ Birlikte Yaşama } & \multirow{2}{*}{ Toplam } & \multirow{2}{*}{$\chi^{2}$} & \multirow{2}{*}{$s d$} & \multirow[b]{2}{*}{$p$} & \multirow{2}{*}{$\begin{array}{c}\text { Cramér's } \\
V\end{array}$} \\
\hline & Evet & Hayır & & & & & \\
\hline Kadın & 243 & 760 & \multirow{2}{*}{1003} & \multirow{5}{*}{44.77} & \multirow{5}{*}{1} & \multirow{5}{*}{.00} & \multirow{5}{*}{.19} \\
\hline Cinsiyetin içinde \% & $\% 24$ & $\% 76$ & & & & & \\
\hline Erkek & 124 & 153 & \multirow{2}{*}{277} & & & & \\
\hline Cinsiyetin içinde \% & $\% 45$ & $\% 55$ & & & & & \\
\hline Toplam & 367 & 913 & 1280 & & & & \\
\hline
\end{tabular}




\begin{tabular}{|c|c|c|c|c|c|c|c|}
\hline \multirow[t]{2}{*}{ Cinsiyet $^{\mathrm{a}}$} & \multicolumn{2}{|c|}{ Cinsellik } & \multirow{2}{*}{ Toplam } & \multirow{2}{*}{$\chi^{2}$} & \multirow{2}{*}{$s d$} & \multirow{2}{*}{$p$} & \multirow{2}{*}{$\begin{array}{c}\text { Cramér's } \\
V\end{array}$} \\
\hline & Evet & Hayır & & & & & \\
\hline Kadın & 212 & 971 & \multirow{2}{*}{1003} & \multirow{5}{*}{20.62} & \multirow{5}{*}{1} & \multirow{5}{*}{.00} & \multirow{5}{*}{.13} \\
\hline Cinsiyetin içinde \% & $\% 21$ & $\% 79$ & & & & & \\
\hline Erkek & 95 & 182 & \multirow{2}{*}{277} & & & & \\
\hline \multirow{2}{*}{$\begin{array}{c}\text { Cinsiyetin içinde } \% \\
\text { Toplam }\end{array}$} & $\% 34$ & $\% 66$ & & & & & \\
\hline & 307 & 973 & 1280 & & & & \\
\hline \multirow[t]{2}{*}{ Cinsiyet $^{\mathrm{a}}$} & \multicolumn{2}{|c|}{ Kayg1 } & \multirow{2}{*}{ Toplam } & \multirow{2}{*}{$\chi^{2}$} & \multirow{2}{*}{$s d$} & \multirow[b]{2}{*}{$p$} & \multirow{2}{*}{$\begin{array}{c}\text { Cramér's } \\
V\end{array}$} \\
\hline & Evet & Hayır & & & & & \\
\hline Kadın & 646 & 357 & \multirow{2}{*}{1003} & \multirow{5}{*}{27.77} & \multirow{5}{*}{1} & \multirow{5}{*}{.00} & \multirow{5}{*}{.15} \\
\hline Cinsiyetin içinde \% & $\% 64$ & $\% 36$ & & & & & \\
\hline Erkek & 130 & 147 & \multirow{2}{*}{277} & & & & \\
\hline Cinsiyetin içinde $\%$ & $\% 47$ & $\% 53$ & & & & & \\
\hline Toplam & 776 & 504 & 1280 & & & & \\
\hline
\end{tabular}

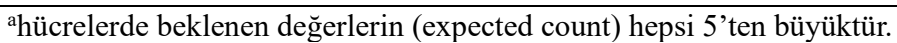

Cinsiyet ile yaşam seyrinde evliliği planlama arasındaki ilişki incelendiğinde sonucun manidar $\left(\chi^{2}(1)=.37, p>.05\right)$ olmadığ belirlenmiştir. Bu sonuca göre yaşamlarında evliliği planlayan üniversite öğrencisi kadın (\%84) ve erkeklerin (\%82) oranları benzerdir.

Cinsiyet ile evliliğe hazır olma arasındaki anlamlı $\left(\chi^{2}(2)=12.92, p<.05\right)$ bir ilişki olduğu tespit edilmiştir. $\mathrm{Bu}$ sonuca ilişkin etki büyüklüğü düşük düzeyde (Cramér's $V=.10$ ) bulunmuştur. $\mathrm{Bu}$ farkın hangi gruplar arasında olduğunu belirlemek için follow-up testler yapılmıştır. Bu testler yapılırken birinci tip hatayı kontrol edebilmek için Holm's Sequential Bonferroni yöntemi kullanılmıştır. Bu yöntemde karşılaş̧ırma sayısının her seferinde bir eksiğine alfa (.05) bölünerek yeni alfa katsayısı belirlenir. Evliliğe hazır olma durumu üç kategori olduğu için alfa önce üçe, sonra ikiye ve en sonunda da bire bölünerek her bir karşılaştırma için alfa katsayısı belirlenmiştir. Başka bir ifadeyle alfa sırasıyla $.017, .025$ ve .05 olarak kabul edilmiştir. Bu ikili karşılaştırmalarda öncelikle kendisini evliliğe hazır hissedenlerle hissetmeyenlerin cinsiyetle ilişkisi incelenmiş ve sonucun $\left(\chi^{2}(1)=12.16, p=.00\right)$ anlamlı olduğu belirlenmiştir. Bu sonuca göre kendisini evliliğe hazır hisseden erkeklerin oranı (\%37) hissetmeyenlere kıyasla (\%20) daha fazladır. İkinci karşılaştırmada kendisini evliliğe hazır hissedenlerle kısmen hazır hissedenlerin cinsiyetle ilişsisi incelenmiştir. Elde edilen bulguya göre $\left(\chi^{2}(1)=11.27, p=.00\right)$ anlamlı bir ilişki olduğu görülmüştür. Başka bir ifadeyle kendini evliliğe hazır hisseden erkeklerin (\%37) oranı bazı konularda evet bazı konularda hayır diyen erkeklere (\%21) kıyasla daha fazladır. Son olarak ise kendilerini kısmen evliliğe hazır hissedenlerle hazır hissetmeyenlerin cinsiyetle ilişkisi incelenmiş ve sonucun manidar $\left(\chi^{2}(1)=.01, p=.94\right)$ olmadığ 1 tespit edilmiştir.

Cinsiyet ile gençlerin yaşam planındaki öncelikleri arasındaki ilişki incelendiğinde sonucun anlamlı $\left(\chi^{2}(1)=30.43, \quad p<.05\right)$ olduğu belirlenmiştir. $\mathrm{Bu}$ sonuca ilişkin etki büyüklüğünün düşük düzeyde (Cramér's $V=.15$ ) olduğu tespit edilmiştir. Bu sonuca göre yaşam planlarında önceliği evlilik olan üniversite öğrencisi erkeklerin oranı (\%28) kadınlara kıyasla (\%14) daha fazladır.

Cinsiyet ile evliliğinin ebeveynlerininkine benzemesini isteme durumu arasındaki ilişki incelenmiş ve sonucun anlamlı $\left(\chi^{2}(1)=6.15, p<.05\right)$ olduğu görülmüştür. $\mathrm{Bu}$ sonuca ilişkin etki büyüklüğünün düşük düzeyde (Cramér's $V=.07$ ) olduğu belirlenmiştir. $\mathrm{Bu}$ sonuca göre evliliklerinin ebeveynlerinin evliliğine benzemesini isteyen üniversite öğrencisi erkeklerin oranı (\%38) kadınlara kıyasla (\%30) daha fazladır.

Cinsiyet ile evliliğe hazırlanmak için evliliğe hazırlık programına katılma durumu arasındaki ilişkinin anlamlı $\left(\chi^{2}(1)=38.98, p<.05\right)$ olduğu görülmüştür. $\mathrm{Bu}$ sonuca ilişkin etki 
büyüklüğünün düşük düzeyde (Cramér's $V=.18$ ) olduğu tespit edilmiştir. Bu sonuca göre evliliğe hazırlanmak için evliliğe hazırlık programına katılmak isteyen üniversite öğrencisi kadınların oranı (\%41) erkeklere kıyasla (\%20) daha fazladır.

Cinsiyet ile evlilik planı yapılmadan partnerle birlikte yaşamanın kabul edilebilir olduğunu düşünme arasındaki ilişkinin anlamlı $\left(\chi^{2}(1)=13.67, p<.05\right)$ olduğu belirlenmiştir. $\mathrm{Bu}$ sonuca ilişkin etki büyüklügünün düşük düzeyde (Cramér's $V=.10)$ olduğu tespit edilmiştir. $\mathrm{Bu}$ sonuca göre evlilik planı yapılmadan partnerle birlikte yaşamanın kabul edilebilir olduğuna evet diyen üniversite öğrencisi erkeklerin oranı (\%39) kadınlara kıyasla (\%28) daha fazladır.

Cinsiyet ile evlilik planı yapılarak partnerle birlikte yaşamanın kabul edilebilir olduğunu düşünme arasındaki ilişkinin anlamlı $\left(\chi^{2}(1)=12.14, p<.05\right)$ olduğu belirlenmiştir. $\mathrm{Bu}$ sonuca ilişkin etki büyüklüğünün düşük düzeyde (Cramér's $V=.10)$ olduğu tespit edilmiştir. $\mathrm{Bu}$ sonuca göre evlilik planı yapılarak partnerle birlikte yaşamanın kabul edilebilir olduğuna evet diyen üniversite öğrencisi erkeklerin oranı (\%46) kadınlara kıyasla (\%34) daha fazladır.

Cinsiyet ile partnerle birlikte evlenmeden birlikte yaşamayı kabul etme arasındaki ilişkinin anlamlı $\left(\chi^{2}(1)=44.77, \quad p<.05\right)$ olduğu belirlenmiştir. $\mathrm{Bu}$ sonuca ilişkin etki büyüklüğünün düşük düzeyde (Cramér's $V=19$ ) olduğu tespit edilmiştir. Bu sonuca göre partnerimle evlenmeden birlikte yaşayabilirim diyen üniversite öğrencisi erkeklerin oranı (\%45) kadınlara kıyasla (\%24) daha fazladır.

Cinsiyet ile evlenmeden (evlilik dışı) cinsel ilişki yaşanmasını uygun bulma arasındaki ilişkinin anlamlı $\left(\chi^{2}(1)=20.62, p<.05\right)$ olduğu görülmüştür. Bu sonuca ilişkin etki büyüklüğünün düşük düzeyde (Cramér's $V=.13$ ) olduğu belirlenmiştir. Bu sonuca göre evlenmeden (evlilik dışı) cinsel ilişki yaşanmasının uygun olduğunu kabul eden erkeklerin oranı (\%34) kadınlara kıyasla (\%21) daha fazladır.

Cinsiyet ile evlilikten kaygılanma durumu arasındaki ilişkinin anlamlı $\left(\chi^{2}(1)=27.77\right.$, $p<.05)$ olduğu görülmüştür. $\mathrm{Bu}$ sonuca ilişkin etki büyüklüğünün düşük düzeyde (Cramér's $V=.15$ ) olduğu belirlenmiştir. Bu sonuca göre evlilikten kaygılanan üniversite öğrencisi kadınların oranı (\%64) erkeklere kıyasla (\%47) daha fazladır.

Tablo 4. İlişki durumuna ilişkin ki-kare analiz sonuçları

\begin{tabular}{|c|c|c|c|c|c|c|c|c|}
\hline \multirow[t]{2}{*}{ İliş̧ki durumu ${ }^{\mathrm{a}}$} & \multicolumn{3}{|c|}{ Evlilik planı } & \multirow{2}{*}{ Toplam } & \multirow[b]{2}{*}{$\chi^{2}$} & \multirow[b]{2}{*}{$s d$} & \multirow[b]{2}{*}{$p$} & \multirow{2}{*}{$\begin{array}{c}\text { Cramér's } \\
V\end{array}$} \\
\hline & Evet & \multicolumn{2}{|c|}{ Hayır } & & & & & \\
\hline Evet & 367 & \multirow{2}{*}{\multicolumn{2}{|c|}{$\begin{array}{l}30 \\
\% 8\end{array}$}} & \multirow{2}{*}{397} & \multirow{5}{*}{33.32} & \multirow{5}{*}{1} & \multirow{5}{*}{.00} & \multirow{5}{*}{.16} \\
\hline İlişki durumu içinde \% & $\% 92$ & & & & & & & \\
\hline Hayır & 702 & & & 883 & & & & \\
\hline \multirow{2}{*}{$\begin{array}{l}\text { İlişki durumu içinde \% } \\
\text { Toplam }\end{array}$} & $\% 79$ & \multicolumn{2}{|c|}{$\% 21$} & 005 & & & & \\
\hline & 1069 & \multicolumn{2}{|c|}{211} & 1280 & & & & \\
\hline \multirow[t]{2}{*}{ İlişki durumu ${ }^{\mathrm{a}}$} & \multicolumn{3}{|c|}{ Evliliğe hazır olma } & \multirow[b]{2}{*}{ Toplam } & \multirow[b]{2}{*}{$\chi^{2}$} & \multirow[b]{2}{*}{$s d$} & \multirow[b]{2}{*}{$p$} & \multirow{2}{*}{$\begin{array}{c}\text { Cramér's } \\
V\end{array}$} \\
\hline & Evet & Kismen & Hayır & & & & & \\
\hline Evet & 35 & 202 & 160 & \multirow{3}{*}{397} & \multirow{7}{*}{37.87} & \multirow{7}{*}{2} & \multirow{7}{*}{.00} & \multirow{7}{*}{17} \\
\hline İlişki durumu içinde \% & $\% 9$ & $\% 51$ & $\% 40$ & & & & & \\
\hline Hazır olmanın içinde \% & $\% 42$ & $\% 39$ & $\% 24$ & & & & & \\
\hline Hayır & 48 & 316 & 519 & \multirow{3}{*}{883} & & & & \\
\hline İlişki durumu içinde \% & $\% 5$ & $\% 36$ & $\% 59$ & & & & & \\
\hline Hazır olmanın içinde \% & $\% 58$ & $\% 61$ & $\% 76$ & & & & & \\
\hline Toplam & 83 & 518 & 679 & 1280 & & & & \\
\hline
\end{tabular}




\begin{tabular}{|c|c|c|c|c|c|c|c|}
\hline \multirow[t]{2}{*}{ İlişki durumu ${ }^{a}$} & \multicolumn{2}{|c|}{ Öncelik } & \multirow{2}{*}{ Toplam } & \multirow{2}{*}{$\chi^{2}$} & \multirow{2}{*}{$s d$} & \multirow{2}{*}{$p$} & \multirow{2}{*}{$\begin{array}{c}\text { Cramér's } \\
V\end{array}$} \\
\hline & Evlilik & Kariyer & & & & & \\
\hline Evet & 87 & 310 & \multirow{2}{*}{397} & \multirow{5}{*}{9.37} & \multirow{5}{*}{1} & \multirow{5}{*}{.00} & \multirow{5}{*}{.09} \\
\hline İlişki durumu içinde \% & $\% 22$ & $\% 78$ & & & & & \\
\hline \multirow{3}{*}{$\begin{array}{l}\text { Hayır } \\
\text { İlişki durumu içinde \% } \\
\text { Toplam }\end{array}$} & 132 & 751 & \multirow{2}{*}{883} & & & & \\
\hline & $\% 15$ & $\% 85$ & & & & & \\
\hline & 219 & 1061 & 1280 & & & & \\
\hline \multirow[t]{2}{*}{ İlişki durumu ${ }^{\mathrm{a}}$} & \multicolumn{2}{|c|}{ Ebeveyn benzeme } & \multirow{2}{*}{ Toplam } & \multirow{2}{*}{$\chi^{2}$} & \multirow{2}{*}{$s d$} & \multirow[b]{2}{*}{$p$} & \multirow{2}{*}{$\begin{array}{c}\text { Cramér's } \\
V\end{array}$} \\
\hline & Evet & Hayır & & & & & \\
\hline \multirow{5}{*}{$\begin{array}{c}\text { Evet } \\
\text { İlişki durumu içinde \% } \\
\text { Hayır } \\
\text { İlişki durumu içinde \% } \\
\text { Toplam } \\
\end{array}$} & 125 & 272 & \multirow{2}{*}{397} & \multirow{5}{*}{.10} & \multirow{5}{*}{1} & \multirow{5}{*}{.75} & \multirow{5}{*}{ - } \\
\hline & $\% 32$ & $\% 68$ & & & & & \\
\hline & 286 & 597 & \multirow{2}{*}{883} & & & & \\
\hline & $\% 32$ & $\% 68$ & & & & & \\
\hline & 411 & 869 & 1280 & & & & \\
\hline \multirow[t]{2}{*}{ İlişki durumu ${ }^{\mathrm{a}}$} & \multicolumn{2}{|c|}{ Program } & \multirow{2}{*}{ Toplam } & \multirow{2}{*}{$\chi^{2}$} & \multirow{2}{*}{$s d$} & \multirow[b]{2}{*}{$p$} & \multirow{2}{*}{$\begin{array}{c}\text { Cramér's } \\
V\end{array}$} \\
\hline & Evet & Hayır & & & & & \\
\hline Evet & 145 & 252 & 397 & & & & \\
\hline İlişki durumu içinde \% & $\% 37$ & $\% 63$ & 391 & & & & \\
\hline Hayır & 318 & 565 & 883 & .03 & 1 & .86 & - \\
\hline İlişki durumu içinde \% & $\% 36$ & $\% 64$ & 005 & & & & \\
\hline Toplam & 463 & 817 & 1280 & & & & \\
\hline
\end{tabular}

\begin{tabular}{|c|c|c|c|c|c|c|c|}
\hline \multirow[t]{2}{*}{ İlişki durumu ${ }^{\mathrm{a}}$} & \multicolumn{2}{|c|}{ Plan Yapılmadan } & \multirow{2}{*}{ Toplam } & \multirow{2}{*}{$\chi^{2}$} & \multirow{2}{*}{$s d$} & \multirow[b]{2}{*}{$p$} & \multirow{2}{*}{$\begin{array}{c}\text { Cramér's } \\
V\end{array}$} \\
\hline & Evet & Hayır & & & & & \\
\hline Evet & 161 & 236 & \multirow{2}{*}{397} & \multirow{5}{*}{28.58} & \multirow{5}{*}{1} & \multirow{5}{*}{.00} & \multirow{5}{*}{.15} \\
\hline İlişki durumu içinde \% & $\% 41$ & $\% 59$ & & & & & \\
\hline \multirow{3}{*}{$\begin{array}{c}\text { Hayır } \\
\text { İlişki durumu içinde \% } \\
\text { Toplam }\end{array}$} & 227 & 656 & \multirow{2}{*}{883} & & & & \\
\hline & $\% 26$ & $\% 74$ & & & & & \\
\hline & 388 & 892 & 1280 & & & & \\
\hline
\end{tabular}

\begin{tabular}{|c|c|c|c|c|c|c|c|}
\hline \multirow[t]{2}{*}{ İlişki durumu ${ }^{\mathrm{a}}$} & \multicolumn{2}{|c|}{ Plan Yapılarak } & \multirow{2}{*}{ Toplam } & \multirow{2}{*}{$\chi^{2}$} & \multirow{2}{*}{$s d$} & \multirow[b]{2}{*}{$p$} & \multirow{2}{*}{$\begin{array}{c}\text { Cramér's } \\
V\end{array}$} \\
\hline & Evet & Hayır & & & & & \\
\hline Evet & 194 & 203 & \multirow{2}{*}{397} & \multirow{5}{*}{37.56} & \multirow{5}{*}{1} & \multirow{5}{*}{.00} & \multirow{5}{*}{.17} \\
\hline İlişki durumu içinde \% & $\% 49$ & $\% 51$ & & & & & \\
\hline \multirow{3}{*}{$\begin{array}{c}\text { Hayır } \\
\text { İlişki durumu içinde \% } \\
\text { Toplam }\end{array}$} & 274 & 609 & \multirow{2}{*}{883} & & & & \\
\hline & $\% 31$ & $\% 69$ & & & & & \\
\hline & 468 & 812 & 1280 & & & & \\
\hline \multirow[t]{2}{*}{ İlişki durumu ${ }^{\mathrm{a}}$} & \multicolumn{2}{|c|}{ Birlikte Yaşama } & \multirow{2}{*}{ Toplam } & \multirow{2}{*}{$\chi^{2}$} & \multirow{2}{*}{$s d$} & \multirow[b]{2}{*}{$p$} & \multirow{2}{*}{$\begin{array}{c}\text { Cramér's } \\
V\end{array}$} \\
\hline & Evet & Hayır & & & & & \\
\hline Evet & 166 & 231 & \multirow{2}{*}{397} & \multirow{5}{*}{48.60} & \multirow{5}{*}{1} & \multirow{5}{*}{.00} & \multirow{5}{*}{.20} \\
\hline İlişki durumu içinde \% & $\% 42$ & $\% 58$ & & & & & \\
\hline Hayır & 201 & 682 & \multirow{2}{*}{883} & & & & \\
\hline İlişki durumu içinde \% & $\% 23$ & $\% 77$ & & & & & \\
\hline Toplam & 367 & 913 & 1280 & & & & \\
\hline
\end{tabular}




\begin{tabular}{|c|c|c|c|c|c|c|c|}
\hline \multirow[t]{2}{*}{ İlişki durumu ${ }^{\mathrm{a}}$} & \multicolumn{2}{|c|}{ Cinsellik } & \multirow{2}{*}{ Toplam } & \multirow{2}{*}{$\chi^{2}$} & \multirow{2}{*}{$s d$} & \multirow[b]{2}{*}{$p$} & \multirow{2}{*}{$\begin{array}{c}\text { Cramér's } \\
V\end{array}$} \\
\hline & Evet & Hayır & & & & & \\
\hline Evet & 139 & 258 & \multirow{2}{*}{397} & \multirow{4}{*}{38.39} & & \multirow{4}{*}{.00} & \multirow{4}{*}{.17} \\
\hline İlişki durumu içinde \% & $\% 35$ & $\% 65$ & & & \multirow{3}{*}{1} & & \\
\hline \multirow{2}{*}{$\begin{array}{c}\text { Hayır } \\
\text { İlişki durumu içinde \% } \\
\text { Toplam }\end{array}$} & $\begin{array}{l}168 \\
\% 19\end{array}$ & $\begin{array}{c}715 \\
\% 81\end{array}$ & 883 & & & & \\
\hline & $\begin{array}{c}\% 19 \\
307\end{array}$ & 973 & 1280 & & & & \\
\hline \multirow[t]{2}{*}{ İlişki durumu ${ }^{\mathrm{a}}$} & \multicolumn{2}{|c|}{ Kayg1 } & \multirow{2}{*}{ Toplam } & \multirow{2}{*}{$\chi^{2}$} & \multirow{2}{*}{$s d$} & \multirow[b]{2}{*}{$p$} & \multirow{2}{*}{$\begin{array}{c}\text { Cramér's } \\
V\end{array}$} \\
\hline & Evet & Hayır & & & & & \\
\hline \multirow{5}{*}{$\begin{array}{c}\text { Evet } \\
\text { İlişki durumu içinde \% } \\
\text { Hayır } \\
\text { İlişki durumu içinde \% } \\
\text { Toplam }\end{array}$} & 216 & 181 & \multirow{2}{*}{397} & \multirow{5}{*}{9.32} & \multirow{5}{*}{1} & \multirow{5}{*}{.00} & \multirow{5}{*}{.09} \\
\hline & $\% 54$ & $\% 46$ & & & & & \\
\hline & 560 & 323 & \multirow{2}{*}{883} & & & & \\
\hline & $\frac{\% 63}{776}$ & $\frac{\% 37}{504}$ & & & & & \\
\hline & 776 & 504 & 1280 & & & & \\
\hline
\end{tabular}

ahücrelerde beklenen değerlerin (expected count) hepsi 5'ten büyüktür.

İlişki durumu ile yaşam seyrinde evliliği planlama arasındaki ilişki incelendiğinde sonucun manidar $\left(\chi^{2}(1)=33.32, p<.05\right)$ olduğu görülmüştür. Bu sonuca ilişkin etki büyüklüğü düşük düzeyde (Cramér's $V=.16$ ) bulunmuştur. Elde edilen bu bulguya göre yaşamlarında evliliği planlayan romantik ilişkisi olan bireylerin oranı (\%92) romantik bir ilişkisi olmayanlara kıyasla (\%79) daha fazladır.

İlişki durumu ile evliliğe hazır olma arasındaki manidar $\left(\chi^{2}(2)=37.87, p<.05\right)$ bir ilişki olduğu tespit edilmiştir. Bu sonuca ilişkin etki büyüklüğü düşük düzeyde (Cramér's $V=.17$ ) bulunmuştur. $\mathrm{Bu}$ farkın hangi gruplar arasında olduğunu belirlemek için follow-up testler yapılmıştır. Cinsiyet ile evliliğe hazır olma arasındaki ilişki analiz edilirken kullanılan yöntem burada da tekrarlanmıştır. Böylece, alfa sırasıyla .017 , .025 ve .05 olarak kabul edilmiştir. Bu ikili karşılaştırmalarda öncelikle kendisini evliliğe hazır hissedenlerle hissetmeyenlerin ilişki durumuyla ilişkisi değerlendirilmiş ve sonucun $\left(\chi^{2}(1)=13.44, p=.00\right)$ anlamlı olduğu belirlenmiştir. Bu sonuca göre romantik ilişkisi olup kendisini evliliğe hazır hissedenlerin oranı (\%42) hissetmeyenlere kıyasla (\%24) daha fazladır. İkinci karşılaştırmada kendisini evliliğe hazır hissedenlerle kısmen hazır hissedenlerin ilişki durumuyla ilişkisi incelenmiştir. Elde edilen bulguya göre $\left(\chi^{2}(1)=.30, p=.58\right)$ anlamlı bir ilişki olmadığı görülmüştür. Başka bir ifadeyle romantik bir ilişkisi olup kendini evliliğe hazır hissedenlerin oranıyla (\%42) bazı konularda evet bazı konularda hayır diyenlerin (\%39) oranı benzerdir. Son olarak ise kendilerini kısmen evliliğe hazır hissedenlerle hazır hissetmeyenlerin ilişki durumuyla ilişkisi incelenmiş ve sonucun anlamlı $\left(\chi^{2}(1)=33.17, p=.00\right)$ olduğu belirlenmiştir. Başka bir ifadeyle romantik bir ilişkisi olup kendini evliliğe kısmen hazır hissedenlerin oranı (\%39) hazır olmayanlara (\%24) kıyasla daha fazladır.

İlişki durumuyla gençlerin yaşam planındaki öncelikleri arasındaki ilişkinin $\left(\chi^{2}(1)=9.37\right.$, $p<.05)$ manidar olduğu belirlenmiştir. Bu sonuca ilişkin etki büyüklüğünün düşük düzeyde (Cramér's $V=.09$ ) olduğu tespit edilmiştir. Bu sonuca göre romantik ilişkisi olup yaşam planlarında önceliği evlilik olan üniversite öğrencilerinin oranı (\%22) romantik bir ilişkisi olmayanlara kıyasla (\%15) daha fazladır.

İlişki durumuyla evliliğinin ebeveynlerininkine benzemesini isteme durumu arasındaki ilişkinin manidar $\left(\chi^{2}(1)=.10, p>.05\right)$ olmadığı görülmüştür. Başka bir deyişle evliliklerinin ebeveynlerinin evliliğine benzemesini isteyen ve istemeyen üniversite öğrencilerinin oranı benzerdir.

İlişki durumuyla evliliğe hazırlanmak için evliliğe hazırlık programına katılma durumu arasındaki ilişkinin anlamlı $\left(\chi^{2}(1)=.03, p>.05\right)$ olmadığ belirlenmiştir. Bu sonuca göre evliliğe hazırlanmak için evliliğe hazırlık programına katılmak isteyen romantik bir ilişkisi olanlarla 
olmayanların oranı benzerdir.

İlişki durumu ile evlilik planı yapılmadan partnerle birlikte yaşamanın kabul edilebilir olduğunu düşünme arasındaki ilişkinin manidar $\left(\chi^{2}(1)=28.58, p<.05\right)$ olduğu görülmüştür. $\mathrm{Bu}$ sonuca ilişkin etki büyüklüğünün düşük düzeyde (Cramér's $V=.15$ ) olduğu tespit edilmiştir. $\mathrm{Bu}$ sonuca göre evlilik planı yapılmadan partnerle birlikte yaşamanın kabul edilebilir olduğuna evet diyen romantik bir ilişkisi olan gençlerin oranı (\%41) romantik bir ilişkisi olmayanlara kıyasla (\%26) daha fazladır.

İlişki durumu ile evlilik planı yapılarak partnerle birlikte yaşamanın kabul edilebilir olduğunu düşünme arasındaki ilişkinin anlamlı $\left(\chi^{2}(1)=37.56, p<.05\right)$ olduğu belirlenmiştir. Bu sonuca ilişkin etki büyüklüğünün düşük düzeyde (Cramér's V=.17) olduğu sonucuna ulaşılmıştır. Bu sonuca göre evlilik planı yapılarak partnerle birlikte yaşamanın kabul edilebilir olduğuna evet diyen romantik bir ilişkiye sahip olan gençlerin oranı (\%49) romantik bir ilişkisi olmayanlara kıyasla (\%31) daha fazladır.

İlişki durumu ile partnerle birlikte evlenmeden birlikte yaşamayı kabul etme arasındaki ilişkinin anlamlı $\left(\chi^{2}(1)=48.60, p<.05\right)$ olduğu görülmüsstür. Bu sonuca ilişkin etki büyüklüğünün düşük düzeyde (Cramér's $V=.20$ ) olduğu tespit edilmiştir. Bu sonuca göre partnerimle evlenmeden birlikte yaşayabilirim diyen romantik bir ilişkisi olan üniversite öğrencilerinin oranı $(\% 42)$ romantik bir ilişkisi olmayanlara kıyasla (\%23) daha fazladır.

İlişki durumu ile evlenmeden (evlilik dışı) cinsel ilişki yaşanmasını uygun bulma arasındaki ilişki incelenmiş ve sonuç $\left(\chi^{2}(1)=38.39, p<.05\right)$ manidar bulunmuştur. $\mathrm{Bu}$ sonuca ilişkin etki büyüklügünün düşük düzeyde (Cramér's $V=.17$ ) olduğu belirlenmiştir. Bu sonuca göre evlenmeden (evlilik dış1) cinsel ilişki yaşanmasının uygun olduğunu kabul eden romantik bir ilişkisi olan gençlerin oranı (\%35) romantik bir ilişkisi olmayanlara kıyasla (\%19) daha fazladir.

İlişki durumu ile evlilikten kaygılanma durumu arasındaki ilişkinin anlamlı $\left(\chi^{2}(1)=9.32\right.$, $p<.05)$ olduğu görülmüştür. $\mathrm{Bu}$ sonuca ilişkin etki büyüklüğünün düşük düzeyde (Cramér's $V=.09$ ) olduğu belirlenmiştir. Bu sonuca göre evlilikten kaygılanan romantik bir ilişkisi olmayan üniversite öğrencilerinin oranı (\%63) romantik bir ilişkisi olanlara kıyasla (\%54) daha fazladır.

\section{Tartışma}

$\mathrm{Bu}$ araştırmanın amacı üniversite öğrencisi gençlerin evliliğe ilişkin görüşlerinin incelenmesidir. Bu amaç doğrultusunda yapılan bu çalışmada gençlerin büyük bir çoğunluğunun yaşam seyirlerinde evlenmeyi planladıkları sonucuna ulaşılmıştır. Bener ve Günay (2013) üniversite öğrencileriyle yaptıkları çalışmada gençlerin büyük bir çoğunluğunun (\%87) evlenmeyi düşündüklerini tespit etmiştirler. Benzer olarak, Bağ (2019) üniversite öğrencileri örnekleminde gerçekleştirdiği çalışmada öğrencilerinin büyük bir çoğunluğunun evlenmek istediklerini rapor etmiştir. Elde edilen bu bulgular bu araştırmanın sonucuyla benzerlik göstermektedir. $\mathrm{Bu}$ çalışma da Türk kültüründe yapılan diğer çalışmalara kıyasla evliliği planlayan gençlerin oranı görece az olsa da elde edilen bulgu Türkiye'de gençler için evlenmenin önemli bir amaç olduğunun göstergesi olarak kabul edilebilir.

Bu çalışma da ideal evlilik yaşı 26 civarında bulunmuştur. Türk kültüründe daha önceki yapılan çalışmalarda (Akbaş ve diğ., 2019; Köroğlu, 2013; Ondaş, 2007; Teke, 2017) ideal evlilik yaş aralıklarının belirlendiği görülmüştür. Akbaş ve diğerleri (2019) kadınlar için 24 yaş erkekler için 25 yaş ve üzerini gençlerin çoğunluğunun ideal evlilik yaşı olarak gördüklerini tespit etmiştir. Köroğlu (2013) üniversite öğrencilerinin çoğunluğu kadınlar için 22-24 yaş aralığını erkekler için ise 25-29 yaş aralığını ideal evlilik yaşı olarak gördüklerini tespit etmiştir. Ondaş (2007) gençlerin yarıdan fazlasının ideal evlilik yaşı olarak 26-29 yaş aralı̆̆ını belirttiğini rapor etmiştir. Teke (2017) üniversite öğrencilerinin hem kadınlar için hem de erkekler için ideal evlilik yaşının 24-26 olduğunu ifade ettiklerini bildirmiştir. Bu bulgulara göre 
değerlendirildiğinde Türk kültüründe ideal evlilik yaşına ilişkin ortalama bir sayı vermenin güç olduğu belirtilebilir. Ancak, TÜİK (2020) verileri incelendiğinde Türkiye'de erkekler için ortalama ilk evlenme yaşı 27.9, kadınlar için ise 25 olduğu görülmüştür. Bu sonuç gençlerin düşündükleri ideal evlilik yaşının pratiklere yansıması olarak düşünülebilir. Batı toplumlarında yapılan çalışmalarda (Carroll ve diğ., 2007; Hall ve Willoughby, 2018) ideal evlilik yaşının 25 yaş civarında olduğu tespit edilmiştir. Türk kültüründe ideal evlilik yaşının daha yüksek olması gençlerin yaşamlarında farklı önceliklerinin olmasıyla açıklanabilir.

$\mathrm{Bu}$ çalışmada üniversite öğrencilerinin yarıdan fazlasının kendini evliliğe hazır hissetmediği ortaya koyulmuştur. Çizmecioğlu (2020) üniversite öğrencisi erkeklerin yarıdan fazlasının kadınların üçte birinin evliliğe hazır hissetmediğini belirlemiştir. Carroll ve diğerleri (2009) üniversite öğrencisi örnekleminde erkeklerin \% 60'1, kadınların ise \% 67'sinin kendilerini evliliğe hazır hissetmediğini bulmuştur. Benzer olarak, Karadă̆ (2006) üniversite öğrencisi örnekleminde yaptığı çalışma da gençlerin yarıdan fazlasının kendisini evliliğe hazır hissetmediğini bildirmiştir. Bu bulgular bu araştırmanın sonucuyla tutarlık göstermektedir. Üniversite öğrencileriyle yapılan çalışmalarda (Akbaş ve diğ., 2019; Köroğlu, 2013; Ondaş, 2007) eğitimini tamamlama ve ekonomik özgürlüğe kavuşmanın evlenebilmek için önem verilen faktörler olduğu rapor edilmiştir. $\mathrm{Bu}$ bağlamda değerlendirildiğinde üniversite öğrencilerinin çoğunluğunun kendisini evliliğe hazır hissetmemesi olağan bir durum olarak kabul edilebilir.

$\mathrm{Bu}$ çalışmanın önemli bir bulgusu da üniversite öğrencisi gençlerin büyük bir çoğunluğun eşiyle flört ederek evlenmek istemesidir. Benzer olarak, Köroğlu (2013) üniversite öğrencilerinin büyük bir çoğunluğunun eşiyle tanışarak evlenmek istedikleri bulgusuna ulaşmıştır. Ondaş (2007) üniversite öğrencileriyle yaptığı çalışmada büyük bir çoğunluğun evlilik öncesinde flört döneminin olması gerektiğine inandıklarını bildirmiştir. Türkiye'de boşanma sayılarındaki artış (TÜİK, 2020) gençlerin eşlerini evlilik öncesinde daha iyi bir şekilde tanımak istemelerini sağlayabilir. Bu birbirini daha iyi tanıma isteği gençlerin evliliğe karar verebilmek için eş adaylarıyla birlikte daha fazla zaman geçirme talebini oluşturabilir. Böylece, gençlerin evlenme biçiminde daha çok flört etmeyi istemeleri açıklanabilir.

$\mathrm{Bu}$ araştırma gençlerin büyük bir çoğunluğunun yaşamlarında önceliklerinin kariyer olduğu sonucunu ortaya çıkarmıştır. Teke (2017) üniversite öğrencilerinin evlenmek için iş sahibi olmayı önemli bir faktör olarak gördüklerini belirlemiştir. Muraco ve Curran (2012) evliliği erteleme nedenleri arasında finansal endişelerini önemli bir yer tuttuğunu rapor etmiştirler. Bu bulgular evlenebilmek için ekonomik faktörlerin öneminin göstergesi olarak kabul edilebilir. Bu bağlamda değerlendirildiğinde gençlerin evlenebilmek için belirli ekonomik koşullara ulaşma isteği ön plana çıkabilir. Bu nedenle belirli ekonomik koşullara ulaşmak için yaşamlarında öncelikleri kariyer olabilir. Willoughby ve diğerleri (2015a) gençlerin yaşamlarında evliliğe kariyere kıyasla daha fazla önem verdiklerini belirlemiştir. Bu bulgu bu araştırmanın sonuçlarıyla tutarlılık göstermemektedir. Bu sonucun ortaya çıkmasında kültürel öğeler ve ülkelerinin ekonomik koşullarının rolü olabilir.

Gençlerin üçte ikisi evliliklerinin ebeveynlerinin evliliğine benzememesini istedikleri belirlenmiştir. Keldal (2017) nitel bir çalışmasında evliliğe bakış açısını etkileyen faktörler arasında kök ailenin önemli bir tema olduğunu bildirmiştir. Willoughby ve diğerleri (2020) ebeveyni boşanmış bireylerin ebeveyni boşanmamış gençlere kıyasla evliliğin önemine, evliliğin merkeziliğine ve evliliğin sürekliliğine ilişkin daha az inanca sahip olduklarını rapor etmiştirler. $\mathrm{Bu}$ açıdan değerlendirildiğinde ebeveynlerin evliliklerinde yaşadıkları sorunların gençleri etkilemesi muhtemeldir. $\mathrm{Bu}$ bağlamda, aile içerisinde sorunlar yaşanıyorsa gençler ebeveynlerin evliliklerine kendi evliliklerinin benzememesini isteyebilirler. $\mathrm{Bu}$ sonucun açıklanmasında bir başka faktör olarak ise değişen yaşam koşullarında evliliğe bakış açısının ve evlilikten beklentilerin farklılık göstermesi kabul edilebilir. Gençler evliliğe ebeveynlerinin baktığı noktadan bakmıyor olabilirler. 
$\mathrm{Bu}$ çalışmada üniversite öğrencilerin yalnızca üçte biri evliliğe hazırlanabilmek için evliliğe hazırlık programına katılmak istedikleri belirlenmiştir. Teke (2017) üniversite öğrencilerinin neredeyse yarıya yakınının evlilik öncesinde aile danışmanlığından yararlanabileceklerini belirttiklerini ortaya koymuştur. Bu bulguya kıyasla bu çalışmada daha az oranda öğrencilerin evliliğe hazırlık programına katılmak istedikleri tespit edilmiştir. Türkiye'de az sayıda evliliğe hazırlık programının (Haskan-Avc1, 2013) uygulanması ve gençlerin neredeyse yarısının aile danışmanlığı hakkında bilgisinin olmaması (Teke, 2017) gençlerin evliliğe hazırlık programlarına katılıp katılmamayı isteme noktasında belirleyici olabilir.

$\mathrm{Bu}$ çalışmada, gençlerin yaklaşık üçte birinin evlilik planı yapılmadan partnerle evlenmeden birlikte yaşamanın kabul edilebilir olduğunu düşündükleri görülmüştür. Bunun yanı sıra partnerimle evlenmeden birlikte yaşarım diyenlerin oranının da örneklemin yaklaşık üçte biridir. Evlilik planı yapılarak partnerle evlenmeden birlikte yaşamanın kabul edilebilir olduğunu düşünen gençlerin oranı ise örneklemin üçte birinden biraz fazladır. Teke (2017) gençlerin büyük bir çoğunluğunun flört edilen kişiyle nikâhtan önce birlikte yaşamayı onaylamadıklarını bildirmiştir. Bağ (2019) gençlerin evlilik öncesinde eş adayıyla birlikte yaşamayı çok az bir kısmının uygun bulduğunu belirlemiştir. Köroğlu (2013) ise gençlere tercih edilen nikâh türünü sorduğunda sadece \% 2'lik bir kısmın "dini ya da resmi ikisine de gerek yoktur" dediklerini ortaya koymuştur. Her ne kadar yukarıda özetlenen çalışmalarda evlenmeden birlikte yaşamın kabul edilirliği düşük olsa da bu çalışmada daha fazla bireyin evlenmeden birlikte yaşamanın kabul edilebilir olduğuna inandıkları belirlenmiştir. Bu bulgu örneklemdeki çeşitlilikten kaynaklanıyor olabilir. Bunun yanı sıra verilerin çevrimiçi (online) olarak toplanması öğrencilerin daha rahat bir şekilde cevap vermelerine olanak sağlayabilir. Bütün bunların ötesinde bu bulgu evliliğe bakış açısındaki değişimin bir işareti olarak da görülebilir.

$\mathrm{Bu}$ araştırmada gençlerin yaklaşık dörtte birinin evlenmeden cinsel ilişki yaşanmasının uygun olduğunu düşündükleri tespit edilmiştir. Deniz (2019) üniversite öğrencileriyle yaptığ çalışmada kadınların yaklaşık dörtte birinin, erkeklerin yaklaşık yarısının evlilik dışı cinsel ilişkiyi onayladıklarını belirlemiştir. Aynı çalışmada gençlerin yarıdan fazlasının evlenecekleri kişide bekârete önem verdikleri sonucunu elde etmiştir. Evcili ve diğerleri (2013) kadın öğrencilerle yaptıkları çalışmada sadece \% 5'inin evlilik öncesi cinsel deneyimi doğru bulduklarını rapor etmiştirler. Elde edilen tüm bu bulgular birlikte değerlendirildiğinde evlilik öncesinde cinsel ilişki yaşanmasına ilişkin tutumların zaman içerisinde değiştiği ifade edilebilir.

$\mathrm{Bu}$ çalışmada gençlerin yarıdan fazlasının evlilikten kaygılandıkları tespit edilmiştir. Köroğlu (2013) gençlerin çok az bir kısmının evlilikten korktuklarını bildirmiştir. Benzer olarak, Bağ (2019) üniversite öğrencilerinin çok az bir bölümünün evlilikten korktuğu sonucuna ulaşmıştır. Bu bulguların aksine, Akbaş ve diğerleri (2019) üniversite öğrencilerinin \% 40'ının evlilikten korktuğu bulgusunu elde etmiş, Teke (2017) ise \%57'sinin evlilikten korktuğunu bildirmiştir. Bu sonuçlar bu konuda literatürde bir tutarlılık olmadığını göstermektedir. Bağ (2019) gençlerin bir kısmının evliliğe yüklediği anlamlar arasında sorumluluğun yer aldığını belirlemiştir. Teke (2017) üniversite öğrencilerinin evlilikten korkma nedenleri arasında sorumluluk almalarının önemli bir yer tuttuğunu ifade etmiştir. Bu açıdan değerlendirildiğinde, gençlerin evlilikten kaygılanma nedenleri arasında evlilik ilişkisinin bilinmezliği ve evlilikle birlikte üstlenilecek sorumluluklara hazır olmamaları görülebilir. Bunların yanı sıra eş adayına güven gibi bazı konularında gençlerin evlilikten kaygılanmalarına yol açacağı düşünülmektedir.

$\mathrm{Bu}$ araştırmanın önemli bir bulgusu da evliliğin genel öneminin kısmen değerini korumasıdır. Köroğlu (2013) üniversite öğrencilerinin büyük bir çoğunluğunun evliliğe önem verdiğini bildirmiştir. Benzer olarak, Bağ (2019) gençlerin büyük bir çoğunluğunun evliliği önemli olarak gördüklerini belirlemiştir. Can (2015) ise "evlilik gereklidir" ifadesine üniversite öğrencilerinin yaklaşık üçte ikisinin tamamen katıldıklarını ortaya koymuştur. Ondaş (2007) üniversite öğrencilerin yarıdan fazlasının evliliğin özgürce davranmayı kısıtlayacağına inandıklarını ifade etmiştir. Akbaş ve diğerleri (2019) gençlerin üçte ikisinin aile kurumunda 
bozulmalar yaşandığını düşündüklerini tespit etmiştirler. Bütün bu bulgular değerlendirildiğinde gençler açısından evlilik değerli olsa da evliliğe ilişkin bazı çekincelerinin olduğu belirtilebilir. $\mathrm{Bu}$ durum da gençlerin evliliğe kısmen önem vermelerine neden olabilir.

$\mathrm{Bu}$ çalışmada gençlerin evliliğe verdikleri özel önem düzeyinin düşük olduğu belirlenmiş̧tir. Willoughby ve Carroll (2010) gençlerin sadece \% 17'sinin "şuan evlenmek istiyorum" ifadesine katıldıklarını bildirmiştirler. Bu bulgu sadece Türkiye'de değil Amerika'da da gençler evliliğe değer verseler de bu durumun pratiğe dönüşmesi noktasında mesafeli yaklaştıkları olarak değerlendirilebilir. Özellikle, evlilik koşulları arasında üniversite öğrencileri için eğitimlerinin tamamlama ve ekonomik özgürlüğe ulaşmanın önemli bir yer tuttuğu (Köroğlu, 2013) bilinmektedir. Bu noktadan bakıldığında üniversite öğrencilerinin içinde bulundukları koşullar evliliğe verdikleri özel önem düzeyini azaltabilir. Bu çalışmada gençlerin büyük bir çoğunluğunun yaşamda önceliklerinin kariyer olduğu ve gençlerin çok az bir kısmının kendini evliliğe hazır hissettiği bulunmuştur. Bu durum da gençlerin evliliğe verdiği özel önem düzeyini azaltabilir.

$\mathrm{Bu}$ çalışmada yaşam planında öncelikleri evlilik olan, evliliklerinin ebeveynlerine benzemesini isteyen, evlilik planı yapılmadan partnerle birlikte yaşamanın kabul edilebilir olduğunu düşünen, evlilik planı yapılarak partnerle birlikte yaşamanın kabul edilebilir olduğunu düşünen, partnerimle evlenmeden birlikte yaşarım diyen ve evlenmeden cinsel ilişki yaşanmasının uygun olduğunu kabul eden erkeklerin oranının kadınlara kıyasla daha fazla olduğu, evliliğe hazırlık programına katılmak isteyen ve evlilikten kaygılanan kadınların oranının ise erkeklere göre daha fazla olduğu bulunmuştur. Keldal ve Atli (2020) erkek olmanın kadınlara kıyasla evliliğe ilişkin daha olumlu tutumlara sahip olmayla ilişkili olduğunu belirlemişlerdir. Özteke-Kozan ve diğerleri (2019) genç kadınların evlenmeme gerekçeleri arasında kariyerin önemli bir yer tuttuğunu ifade etmiştirler. Bener ve Günay (2013) kadın ve erkeklerin evlilik öncesi birlikte yaşamaması gerektiğine kadınların daha fazla inandığını tespit etmiş̧irler. İşmen-Gazioğlu (2006) kadınların erkeklere kıyasla kariyer sahibi olmanın evlilikten daha önemli olduğunu düşündüklerini bildirmiştir. Ondaş (2007) kadınların erkeklere göre evliliğin, cinselliğin daha rahat yaşanmasına olanak sağladığını düşündüklerini rapor etmiştir. Elde edilen bütün bu bulgular bu araştırma sonucunu destekler niteliktedir. Bu araştırmanın bulguları yorumlanırken içerisinde bulunulan toplumun kültürel etkilerinin de inkâr edilemeyeceği göz önünde bulundurulabilir. Cinsiyet açısından farklılıkların ortaya çıkmasında kültürel öğelerin önemli bir yer tuttuğu düşünülmektedir.

$\mathrm{Bu}$ araştırmada yaşam seyrinde evliliği planlayan, yaşam planında önceliği evlilik olan, evlilik planı yapılmadan partnerle birlikte yaşamanın kabul edilebilir olduğuna inanan, evlilik planı yapılarak partnerle birlikte yaşamanın kabul edilebilir olduğuna inanan, partnerimle evlenmeden birlikte yaşayabileceğini ifade eden ve evlenmeden cinsel ilişki yaşanmasının uygun olduğunu kabul eden romantik bir ilişkisi olan üniversite öğrencilerinin oranının olmayanlara kıyasla daha fazla olduğu, romantik bir ilişkisi olmayıp evlilikten kaygı duyan gençlerin oranının romantik bir ilişkisi olanlara göre daha fazla olduğu görülmüştür. Türk kültüründe daha önceki araştırmalarda (Karabacak ve Çiftçi, 2015; Keldal ve Atli, 2020) romantik bir ilişkisi olanların evliliğe ilişkin daha olumlu tutumlara sahip oldukları belirlenmiştir. Willoughby ve Carroll (2010) flört eden gençlerin evliliği önemli bir amaç olarak gördüklerini ifade etmiştirler. Keldal ve Atli (2020) üniversite öğrencileri için romantik ilişkilerinin olmasının evliliğe hazırlık süreci olarak düşünebileceğini belirtmişlerdir. Gençlerin romantik bir ilişkilerinin olması onların evliliğe adım atabilmelerinde kolaylaştırıcı bir faktör olabilir ve gençlerin partnerleriyle ilişkilerini test edebilmek için evlenmeden birlikte yaşama daha olumlu yaklaşabilirler.

\section{Sonuç ve Öneriler}

$\mathrm{Bu}$ araştırmanın bulguları yorumlanırken birkaç sınırlılık göz önünde bulundurulmalıdır. İlk olarak bu araştırmanın verileri olasılıksız bir örnekleme stratejisi (uygun 
örnekleme) kullanılarak toplanılmıştır. Bu nedenle bu araştırmanın bulguları bütün üniversite öğrencilerine genellenemeyebilir. Bunun yanı sıra bu araştırmada örneklem grubunu ağırlıklı olarak kadınlardan oluşmuştur. $\mathrm{Bu}$ araştırmada cinsiyet açısından farklılıklar olsa da bu farklı1ıklara ilişkin etki büyüklüğü düşük düzeydedir. İlerideki çalışmalarda olasılıklı bir örnekleme stratejisi kullanılarak kadın ve erkek öğrencilerin dengeli dağılım gösterdiği bir örneklemde veriler toplanarak bu araştırmanın sonuçlarının tekrarlanabilir olup olmadığ incelenebilir. Bu araştırmanın bir diğer önemli sınırlılığı da kesitsel olarak tasarlanmasıdır. Bu nedenle üniversite öğrencilerin evliliğe ilişkin görüşlerindeki zaman içerisindeki değişimler belirlenememiştir. İlerideki yapılacak çalışmalar boylamsal olarak tasarlanarak gençlerin evliliğe ilişkin görüşlerindeki zaman içerisindeki değişimler değerlendirilebilir.

$\mathrm{Bu}$ araştırmanın bazı sınırlıkları olmasına rağmen literatüre önemli katkılarının olduğu düşünülmektedir. Özellikle, üniversite öğrencilerinin ideal evlilik yaş ortalamaları, evlenmeden birlikte yaşama ilişkin tutumları ve yaşam planlarındaki önceliklerinin geniş bir örneklemde belirlenmesi yönüyle bu çalışmanın değerli olduğu ifade edilebilir. Bunların yanı sıra evliliğe verilen genel ve özel önem düzeylerinin ortaya koyulması yönüyle bu çalışma önem arz etmektedir. Ayrıca, bu araştırmanın sonuçlarının Türk kültüründe gençlerin evlilik algılarındaki değişimlerin tespit edilmesi açısından önemli olduğu belirtilebilir. Sağlıklı evlilik birliklerinin oluşturulmasında evlilikle ilgili inançların rolü göz önünde bulundurulduğunda bu çalışmanın bulguları evlilik birliğinin temellerinin sağlıklı şekilde atılması için birçok evlilik ve aile danışmanının uygulamalarında yararlanabileceği bir kaynak olarak nitelendirilebilir. Bekâr Türk gençlerinin evlilik ile ilgili inançlarının ortaya konulması son yıllarda Türkiye'de artan boşanma ve azalan evlenme oranlarıyla ilgili politika yapıcıların eylem planları oluşturabilmelerinde yol gösterici olabilir.

\section{Kaynakça}

Akbaş, M., Sürücü, Ş. G., Köroğlu, C. O., \& Öztürk, M. (2019). Factors affecting marriage attitudes of university students. Cukurova Medical Journal,44(1), 93-100. https://doi.org/10.17826/cumj.441022

Bağ, H. (2019). Sosyal hizmet ögrencilerinin eş seçimi ve evliliğe iliş̧kin tercihleri (Yüksek lisans tezi). Üsküdar Üniversitesi, İstanbul.

Barr, A. B., \& Simons, R. L. (2018). Marital beliefs among African American emerging adults: The roles of community context, family background, and relationship experiences. Journal of Family Issues, 39(2), 352-382. https://doi.org/10.1177/0192513X16644640

Bayoğlu, F. ve Atli, A. (2014). İnönü evlilik tutum ölçeği: Geçerlik ve güvenirlik analizleri. Ege Ĕgitim Dergisi, 15(2), 397-415.

Bener, Ö. ve Günay, G. (2013). Gençlerin evlilik ve aile yaşamına ilişkin tutumları. Karabük Üniversitesi Sosyal Bilimler Enstitüsü Dergisi, 3(1), 1-16.

Bozgeyikli, H., \& Toprak, E. (2013). Üniversiteli gençlerin eş seçim kriterlerinin sıralama yargılarıyla ölçeklenmesi. Gençlik Araştırmaları Dergisi, 1(1), 68-87.

Can, Y. (2015). Üniversite öğrencilerinin aile, cinsiyet rolleri ve kadına yönelik şiddete ilişkin tutumlar1. International Journal of Social Sciences and Education Research, 1(1), 163-175. https://doi.org/10.24289/ijsser.106407

Carroll, J. S., Badger, S., Willoughby, B. J., Nelson, L. J., Madsen, S. D., \& McNamara Barry, C. (2009). Ready or not? Criteria for marriage readiness among emerging adults. Journal of adolescent research, 24(3), 349-375. https://doi.org/10.1177/0743558409334253 
Carroll, J. S., Willoughby, B., Badger, S., Nelson, L. J., McNamara Barry, C., \& Madsen, S. D. (2007). So close, yet so far away: The impact of varying marital horizons on emerging adulthood. Journal of Adolescent Research, 22(3), 219-247. https://doi.org/10.1177/0743558407299697

Cherlin, A. J. (2004). The deinstitutionalization of American marriage. Journal of marriage and family, 66(4), 848-861. https://doi.org/10.1111/j.0022-2445.2004.00058.x

Christensen, L. B., Johnson, B., Turner, L. A., \& Christensen, L. B. (2014). Research methods, design, and analysis (Global ed.). London: Pearson.

Çizmecioğlu, R. (2020). Evlilik olgunluğu ile evlilik beklentisi arasındaki ilişkinin incelenmesi (Yüksek Lisans Tezi). İstanbul Ticaret Üniversitesi, İstanbul.

Deniz, A. B. (2019). Üniversite öğrencilerinin aile ve evliliğe iliş̧kin görüşlerinin belirlenmesi (Yüksek Lisans Tezi). Bahçeşehir Üniversitesi, İstanbul.

Evcili, F., Cesur, B., Altun, A., Güçtaş, Z., \& Sümer, H. (2013). Evlilik öncesi cinsel deneyim: Ebelik bölümü öğrencilerinin görüş ve tutumları. Gümüşhane Üniversitesi Săğlk Bilimleri Dergisi, 2(4), 486-498.

Gay, L. R., Mills, G. E., \& Airasian, P. W. (2011). Educational research: Competencies for analysis and application (10 $0^{\text {th }}$ ed.). New Jersey: Pearson.

Green, S. B., \& Salkind, N. J. (2013). Using SPSS for the MacIntosh and Windows: Analyzing and understanding data ( $7^{\text {th }}$ ed.). New Jersey: Pearson.

Hall, S. S., \& Willoughby, B. J. (2018). Opposite-sex siblings and marital beliefs among emerging adults. Journal of Adult Development, 25(1), 61-67. https://doi.org/10.1007/s10804-017-9275-8

Haskan-Avcı, Ö. (2013). Evliliğe hazırlık programının çift ilişkileri ve ilişsi istikrarı üzerindeki etkisi (Doktora tezi). Hacettepe Üniversitesi, Ankara.

Huck, S. W. (2011). Reading statistics and research (6th ed.). Boston, MA: Pearson.

İşmen-Gazioğlu, A. E. (2006). Genç yetişkinlerin evlilik ve aile hayatına ilişkin görüşlerinin değerlendirilmesi. M.Ü. Atatürk Ĕgitim Fakültesi Ĕ̆itim Bilimleri Dergisi, 23(23), 107-123.

Jensen, T. M., Willoughby, B. J., Holman, T. B., Busby, D. M., \& Shafer, K. (2015). Associations between family and interpersonal processes and emerging adult marital paradigms: Does adult attachment mediate?. Journal of Adult Development, 22(1), 50-62. http://dx.doi.org/10.1007/s10804-014-9200-3

Karabacak, A., \& Çiftçi, M. (2015). Üniversite öğrencilerinin evliliğe ilişkin tutumları ile romantik ilişkilerde akılcı olmayan inançları arasındaki ilişkinin incelenmesi. Psikoloji Çalışmaları, 36(2), 25-43.

Karadağ, S. (2006). Dating behaviors, views of marriage and marital preparation among university students in Kyrgyzstan. Manas Üniversitesi Sosyal Bilimler Dergisi, 16, 207-218.

Keldal, G. (2016). Personality traits as a predictor of university students' attitudes towards marriage. Proceedings of 1. International Academic Research Congress, Antalya, Turkey, 2383-2388.

Keldal, G. (2017, Eylül). Bekâr bireylerin evliliğe bakış açılarının incelenmesi. I. Uluslararası İpekyolu Akademik Çalışmalar Sempozyumu, 21-23 Eylül 2017, Nevşehir, Türkiye.

Keldal, G., \& Atli, A. (2020). Predictors of Turkish University students' marital attitudes. Current Psychology, 39(4), 1354-1361. https://doi.org/10.1007/s12144-018-98426 
Koçyiğit-Özyiğit, M. (2017). The meaning of marriage according to university students: A phenomenological study. Educational Sciences: Theory \& Practice, 17(2), 679-711. https://doi.org/10.12738/estp.2017.2.0061

Köroğlu, T. (2013). Üniversite gençliğinde evlilik, aile ve boşanma konusundaki düşünce ve görüsleri üzerine sosyolojik bir araştırma: Karabük Üniversitesi örneği (yüksek lisans tezi). Karabük Üniversitesi, Karabük.

Kuperberg, A. (2019). Premarital cohabitation and direct marriage in the United States: 19562015. Marriage \& Family $\quad$ Review, 55(5), $447-475$. https://doi.org/10.1080/01494929.2018.1518820

Lichter, D. T., Turner, R. N., \& Sassler, S. (2010). National estimates of the rise in serial cohabitation. Social Science Research, 39(5), 754-765. https://doi.org/10.1016/j.ssresearch.2009.11.002

Muraco, J. A., \& Curran, M. A. (2012). Associations between marital meaning and reasons to delay marriage for young adults in romantic relationships. Marriage \& Family Review, 48(3), 227-247. https://doi.org/10.1080/01494929.2012.665013

Ondaş, B. (2007). Üniversite ögrrencilerinin evlilik ve eş seçimi ile ilgili görüşlerinin incelenmesi (Yüksek Lisans Tezi). Gazi Üniversitesi, Ankara.

Öz-Soysal, F. S., Uz Baş, A. ve Aysan, F. (2020). Üniversite öğrencilerinin evlilik beklentisine yönelik nitel bir çalışma. İnönü Üniversitesi Eğitim Fakültesi Dergisi, 21(1), 241-253. https://doi.org/10.17679/inuefd.491512

Özabacı, N., Körük, S. ve Kara, A. (2018). Evliliğe Yüklenen Anlam Ölçeğinin (EYAÖ) Geliştirilmesi: Geçerlik ve güvenirlik çalışması. Türk Psikolojik Danışma ve Rehberlik Dergisi, 8(50), 235-259.

Özteke-Kozan, H. İ., Baloğlu, M., Kesici, Ş. ve Kamer, Z. (2019). Genç kızların evliliğe ilişkin görüşlerinin incelenmesi: Neden evlenirim? Neden evlenmem? Mehmet Akif Ersoy Üniversitesi Eğitim Fakültesi Dergisi, 50, 303-323. https://doi.org/10.21764/maeuefd.520263

Sancak-Aydın, G. ve Demir, A. (2017). Lisansüstü öğrencilerinin eş seçimini etkileyen ve sınırlandıran görüş ve inançları. Ege Eğitim Dergisi, 18(2), 627-652. https://doi.org/10.12984/egeefd.322401

Teke, E. (2017). Üniversite ögrrencilerinin evlilik ve aileye bakışı. (Yüksek Lisans Tezi). Selçuk Üniversitesi, Konya.

Türkiye İstatistik Kurumu (TÜIK). (2020). Evlenme ve boşanma istatistikleri. http://www.tuik.gov.tr/PreTablo.do?alt_id=1060 adresinden ulaş1lmıştır.

Usluoğlu, F., Atıcı, M., \& Avcıbay, B. V. (2015). Women's opinions about mate choices: A qualitative study. Journal of Human Sciences, 12(2), 1484-1502.

Ünal, S. ve Avcı, D. (2019). Kolektiviteden bireyciliğe geçiş: Aile ve evlilik kurumuna dair değişen göstergeler ve kaygılar. Turkish Studies-Social Sciences, 14(5), 2641-2668. https://doi.org/10.29228/TurkishStudies.37350

Willoughby, B. J., \& Carroll, J. S. (2010). Sexual experience and couple formation attitudes among emerging adults. Journal of adult development, 17(1), 1-11. https://doi.org/10.1007/s10804-009-9073-z

Willoughby, B. J., \& Dworkin, J. (2009). The relationships between emerging adults' expressed desire to marry and frequency of participation in risk-taking behaviors. Youth \& Society, 40(3), 426-450. https://doi.org/10.1177/0044118X08318116 
Willoughby, B. J., \& Hall, S. S. (2015). Enthusiasts, delayers, and the ambiguous middle marital paradigms among emerging adults. Emerging Adulthood, 3(2), 123-135. http://dx.doi.org/ 10.1177/2167696814548478

Willoughby, B. J., Hall, S. S., \& Goff, S. (2015a). Marriage matters but how much? Marital centrality among young adults. The Journal of psychology, 149(8), 796-817. https://doi.org/10.1080/00223980.2014.979128

Willoughby, B. J., Hall, S. S., \& Luczak, H. P. (2015b). Marital paradigms: A conceptual framework for marital attitudes, values, and beliefs. Journal of Family Issues, 36(2), 188211. https://doi.org/10.1177/0192513X13487677

Willoughby, B. J., James, S., Marsee, I., Memmott, M., \& Dennison, R. P. (2020). "I'm Scared because Divorce Sucks": Parental Divorce and the Marital Paradigms of Emerging Adults. Journal of Family $\quad$ Issues, 41(6), 711-738. https://doi.org/10.1177/0192513X19880933

\section{ETIKK ve BİLIMSEL İLKELER SORUMLULUK BEYANI}

$\mathrm{Bu}$ çalışmanın tüm hazırlanma süreçlerinde etik kurallara ve bilimsel atıf gösterme ilkelerine riayet edildiğini yazar(lar) beyan eder. Aksi bir durumun tespiti halinde Afyon Kocatepe Üniversitesi Sosyal Bilimler Dergisi'nin hiçbir sorumluluğu olmayıp, tüm sorumluluk makale yazarlarına aittir. Yazarlar etik kurul izni gerektiren çalışmalarda, izinle ilgili bilgileri (kurul adı, tarih ve sayı no) yöntem bölümünde ve ayrıca burada belirtmişlerdir.

Kurul adı: Niğde Ömer Halisdemir Üniversitesi Etik Kurulu

Tarih: 01/07/2020

No: 2020/06-10 